\title{
Penicillium Arizonense as a Novel Producer Strain for Mycophenolic Acid and Expression Analysis of Biosynthesizing Gene Clusters
}

Hala Ammar ( $\square$ halamar2014@gmail.com)

Zagazig University

Saeid Ezzat

Zagazig University

Ebrahim Elshourbagi

Animal Health Research Institute, Egypt

Hind Elshahat

Zagazig University

\section{Research Article}

Keywords: Mycophenolic acid, Penecillium arizonense, mutagenesis, gene expression

Posted Date: January 4th, 2022

DOI: https://doi.org/10.21203/rs.3.rs-1176244/v1

License: @ (i) This work is licensed under a Creative Commons Attribution 4.0 International License. Read Full License 


\section{Abstract}

A novel potent mycophenolic acid (MPA) producer strain of the genus Penicillium was isolated from refrigerated Mozzarella cheese and identified as $P$. arizonenseHEWt1. The molecular mechanism of MPA production by this new isolate was our main target. To achieve this objective, we first isolated three MPA overproducer mutants by exposing the wild type to different doses of gamma-rays, and the fermentation conditions for the highest production of MPA by both the wild type and mutants were optimized. Then, orthologs of MPA gene clusters in $P$. brevicompactum were cloned and predicted from the genome of $P$. arizonense. Sequencing and bioinformatic analysis proved the presence of a cluster containing five putative genes in the $P$. arizonense HEWt1 genome ortholog to the MPA cluster, $m p a A, m p a C, m p a F, m p a G$, and $m p a H$. All predicted genes displayed 96$97 \%$ similarity with the related hypothetical protein of $P$. arizonense. The genes, $m p a G, m p a C$, and $m p a F$. represented $69 \%, 82 \%$, $84 \%$, respectively, similarity with their orthologous genes in P. brevicompactum, whereas mpaG and $m p a A$ represented $75 \%$ and $79 \%$, respectively, similarity to their orthologous genes in $P$. roqueforti. Gene expression analysis through quantitative rPCR indicated an increase in the transcription value of all annotated genes in the three mutants over the wild type. A highly significant increase in the gene expression of $\mathrm{mpaC}, \mathrm{mpaF}$, and $\mathrm{mpaH}$ was observed, with 8.4561 $\pm 1.02,5.6569 \pm 0.87$, and 4.6268 \pm 0.18 -fold increases, respectively, in $P$. arizonenseMT1 compared with wild-type. These results confirmed the potential participation of these genes in MPA biosynthesis and are the first report regarding the molecular mechanism of MPA production by $P$. arizonense.

\section{Introduction}

The wide metabolic variety within the fungal kingdom continues to supply an opulent source for novel drugs. The physiological and chemical diversity in the fungal kingdom leads to the identification of novel bioprocesses depending on fungi that can meet the demands of the current society for creative pharmaceuticals and antimicrobials. Huge numbers of secondary metabolites were previously detected in the fungal kingdom; however, the evolution from the discovery of proper bioactive secondary metabolites to their applications remains a challenge. Penicillium is a diverse genus distributed worldwide in various habitats. Although DNA sequences are necessary for the strong identification of different species of Penicillium, there is currently no universal reference database for verification of its genus. Penicillium genera contain more than 354 accepted species [1], which are a vital industrial unit for the biosynthesis of many chemically and structurally diverse bioactive secondary metabolites, including significant pharmaceutical compounds [2,3]. However, the representation of the fungal kingdom in industrial bioprocesses is still limited, and the improvement of the production of significant compounds is considered an intensive challenge and remains expensive. Mycophenolic acid (6-(4-hydroxy-6-methoxy methyl 3oxophthalanyl)-4-methyl-4-hexenoic acid, C17H2006 (MPA) is a famous secondary metabolite [4] that was discovered as a product of a strain of Penicillium brevicompactum before the start of the 20th century. Some Penicillium species have produced it, including $P$. brevicompactum, $P$. viridicatum, $P$. stoloniferum and $P$. roqfourti $[5,6$, 7]. Mycophenolic acid and its precursors, 5-methylorsellinic acid and 5,7dihydroxy4-methylphthalide, were also identified as secondary metabolites of the yeast Byssochlamys nivea [8]. Due to its immunosuppressive and antimicrobial properties, it has been characterized as an important bioactive compound with various biomedical applications, including immunosuppressive and antimicrobial applications [9]. Additionally, MPA has regular medical applications as an immunosuppressive drug in the form of mycophenolate mofetil, which has been used to treat different autoimmune diseases $[4,10,11]$. Much interest has been directed to the industrial production of MPA due to its potent antiviral effects $[12,13]$. Recent studies proved that MPA has effective antiviral activity against MERS-CoV, human coronavirus (HCoV)OC43, HCoV-NL63, and SARS-CoV-2 $[14,15,16]$ and reported that the combination of MPA and interferon can be used for the treatment of COVID-19. For this intensive importance of MPA, it is necessary to search for a new Penicillium species to produce MPA and to improve its productivity through the batch fermentation process. Cheese is a favorable substrate for the growth of various species of Penicillium because of its favorable preservation conditions for fungal growth, such as low temperature and moisture content. Previous studies reported the distribution of Penicillium species in a wide range of refrigerated cheeses [17]. Although there seems to be no record about the appearance of harmful effects in humans following the consumption of fermented blue cheese, scientific research has increased attention on the production of some secondary metabolites by Penicillium species isolated from these cheeses. A known metabolite of Penicillium connected with blue cheeses is mycophenolic acid (MPA) $[18,19]$. Therefore, it was used as a source for the isolation of a new MPA producer species belonging to the Penicillium genus. 
The molecular basis of MPA biosynthesis was recently investigated in both $P$. brevicompactum and $P$. roqueforti $[6,20,21,22]$. The MPA gene cluster in $P$. brevicombactom consists of 8 open reading frames named $m p a A, m p a B, m p a C, m p a D, m p a E, m p a F$, $m p a G$, and $m p a H$, which encode a putative prenyltransferase, a protein with unknown function, a polyketide synthase, a natural fusion of a cytochrome P450 domain and a hydrolase domain, an inosine-5'-monophosphate dehydrogenase, IMPDH, an 0methyltransferase, and an oxidative cleavage enzyme, respectively $[6,20,21]$. $m p a C$ is responsible for the first step in MPA biosynthesis through the production of 5-methylorsellinic acid (5-MOA, which is encoded by polyketide synthase) [6]. Moreover, it was recently illustrated that the $m p a F$ gene encodes an MPA-insensitive inosine-5=-monophosphate dehydrogenase (IMPDH), which confers self-resistance toward MPA $[20,23]$. The investigation of the molecular basis of MPA production in producer fungal species is a significant impact to facilitate the understanding of the mechanism of its production and to control how it can be improved, especially when the producer species is the first record. The gene cluster of the bioactive metabolites typically consists of the genes that confer the needful toleration to the compounds. MPA is an inhibitor of IMPDH, which is responsible for the conversion of IMP to XMP in the novel pathway of GMP biosynthesis [24]. This reaction is important for all living microorganisms. Inosine 5'-monophosphate dehydrogenase (IMPDH) genes are highly conserved among various species of microorganisms.

P. arizonense is a strong producer of various secondary metabolites and different proteins involved in carbohydrate metabolism. Large numbers of secondary metabolites, such as tryptoquivalines, pyripyropenes, austalides, fumagillin, pseurotin A, xanthoepocin, and curvulinic acid, were investigated in the cell extract of $P$. arizonense [3]. Genome sequencing analysis of $P$. arizonense was assembled into $33.7 \mathrm{Mb}$ containing 12,502 predicted genes [3]. Between these genes, 62 putative biosynthetic gene clusters are involved in lipid metabolism and secondary metabolite production. To date, there have been several incompletely annotated open reading frames (ORFs) in the $P$. arizonense genome. For these reasons, we aimed to overproduce MPA by a novel producer species of Penicillium, namely, $P$. arizonense, and to investigate the molecular basis of its production through identification and cloning of the synthesizing gene cluster of $P$. arizonense that is orthologous to the MPA biosynthesizing gene cluster in $P$. brevicombactum. We also focused on studying the gene expression of the related gene cluster in combination with a physiological analysis of MPA production. There is no previous study on the production and molecular basis of MPA by P. arizonense.

\section{Material And Methods}

\subsection{Chemicals}

All chemicals used in this study were purchased from Sigma Chemical Co. (St. Louis, MO). The stock solution of MPA was prepared by dissolving $1 \mathrm{mg} / \mathrm{ml}$ mycophenolic acid in methanol and stored in the dark at $4{ }^{\circ} \mathrm{C}$.

\subsection{Culture media}

Six types of culture media were used in this study. Czapek-Dox's -yeast extract medium (CDY) was composed of 20 (g/l): sucrose 30, NaNO3 3, KH2PO4 0.5, KCl 0.5, MgSO4.7H2O 0.5, and 0.5 yeast extract FeSO4.7H2O 0.01 (g/l). Yeast extract-sucrose medium (YES) composed of $(20 \mathrm{~g} / \mathrm{l})$ : Sucrose 50, yeast extract. Potato-dextrose medium composed of $(\mathrm{g} / \mathrm{l})$ : peeled potato slices 200 , glucose 20. Yeast peptone dextrose (YPDA) was composed of (g/l): $10.0 \mathrm{~g}$ yeast extract, $20.0 \mathrm{~g}$ peptone, $20.0 \mathrm{~g}$ dextrose, and $20.0 \mathrm{~g}$. Malt extract sucrose (MES) medium was composed of (g/L): 150.0 sucrose, 20.0 malt extract, 0.5 MgS04.7H2O. Glucose peptone medium (LCG) composed of (g/L): 150.0 D-Glucose, 5.0 peptone, 1.0 K2HP04, 0.5 MgSO4.7H2O, $5.0 \mathrm{NaCl}$ and $1000 \mathrm{ml}$ distilled $\mathrm{H} 2 \mathrm{O}$.

\subsection{Microorganism and Inoculum Preparation}

The fungal strain was isolated from different Mozzarella cheeses located in Egyptian markets. The experimental fungus Penicillium arizonense used in this work was preserved on potato dextrose agar (PDA) slants at $4{ }^{\circ} \mathrm{C}$.

\subsection{Morphological and Molecular Identification of Isolated Fungi}


The purified isolates were subcultured on potato dextrose agar medium (PDA) and allowed to grow at $25^{\circ} \mathrm{C}$ for 7 days. Morphological identification was performed according to Raper and Fennell [25] and Pitt and Hocking [26]. Molecular identification of the experimental MPA producer strain was also analyzed to confirm the morphological identification. Genomic DNA was extracted from 3-day-old cultures according to the CTAB method [27, 28]. Briefly, the cell walls of fungal mycelia were broken down by grinding with glass rods or in the presence of liquid nitrogen. CTAB extraction buffer was then added, incubated at $65^{\circ} \mathrm{C}$, and purified with phenol:chloroform:isoamyl alcohol (25:24:1). The extracted genomic DNA was precipitated with cold isopropanol and washed twice with cold 70\% ethyl alcohol. Finally, the DNA was dissolved in $50 \mu$ of sterilized distilled water.

The fungal isolate was identified by ITS rDNA sequencing analysis (18S, $28 \mathrm{~S}$ rRNA, flanking ITS 1, 5.8S rRNA, and ITS 2) according to White et al. [29]. The primer sequences of the ITS1 and ITS4 primers were 5'-TCCGTAGGTGAACCTGCGG-3' and 5'TCCTCCGCTTATTGATATGC-3', respectively. PCR analysis was carried out according to Sambrook and Russell [30]. The released sequence was deposited in the GenBank database, and Molecular Evolutionary Genetic Analysis (MEGA version X) software was used for phylogenetic analyses [31]. The closet homologous sequences were selected, and multiple sequence alignments were carried out using the Clustal W program in MEGAX software. A phylogenetic tree was constructed using the neighbor-joining method with 1,000 bootstrap replicates based on ITS gene sequences to show the phylogenetic relationships between fungi, the two fungal isolates used for OTA production and the closely related strains retrieved from NCBI GenBank.

\subsection{Estimation of MPA}

\section{Thin layer chromatography analysis}

MPA was determined qualitatively using TLC. The methanol extract samples were loaded with the reference standard of MPA on TLC plates using the solvent system toluene:ethyl acetate:formic acid (6:3:1, v:v:v). MPA, with an Rf value of 0.65 , showed blue fluorescence spots under longwavelength ultraviolet light. The spots were visualized by exposing the plates to ammonia vapor before observation under ultraviolet light. The fluorescent spots that appeared identical to the authentic MPA were scraped off and eluted with chloroform. MPA was then quantified by ultraviolet spectroscopic analyses performed with a T80+UV Flash spectrophotometer PG Instrument LTD, UK spectrophotometer, UK. MPA absorption was measured at $304 \mathrm{~nm}$, and the concentration was obtained after recording the optical density against a standard curve [32].

\section{High-performance liquid chromatography (HPLC) analysis}

The purified MPA was further analyzed using high-performance liquid chromatography (HPLC) using HPLC, EZChrom Elite Client/Server, Agilent, USA. The sample was collected and dissolved in $1 \mathrm{~mL}$ methanol, filtered through a $0.45 \mu \mathrm{m}$ filter and analyzed by HPLC (Waters Alliance HPLC) with a C18 column $(5 \mu \mathrm{m}, 4.6 \times 250 \mathrm{~mm})$ at $40{ }^{\circ} \mathrm{C}$. The mobile phase was water and acetonitrile ( $50: 50$ by volume) at pH 3 and a flow rate of $0.5 \mathrm{~mL} / \mathrm{min}$. The injection volume was $20 \mu \mathrm{L}$. A photodiode array detector was used at a wavelength of $220 \mathrm{~nm}$. The standard curve used in this experiment was prepared by HPLC grade authentic MPA (HIMEDIA). The stock solution of MPA $(1 \mathrm{mg} / \mathrm{mL})$ was prepared in methanol and stored at $20^{\circ} \mathrm{C}$. The working solution of MPA in the range of $10-100 \mu \mathrm{g} / \mathrm{mL}$ was prepared by serial dilution of the stock solution with methanol.

\subsection{Inducing Mutagenesis}

The irradiation process was carried out by exposing the wild-type $P$. arizonense strain to different gamma rays at the National Center for Radiation Research and Technology (NCRRT), Nasr City, Cairo, Egypt. The fungal spore suspensions were exposed to various doses of ${ }^{60} \mathrm{Co}$ y-rays $(150,200,250,500$, and $750 \mathrm{~Gy}$ ) emitted by an Indian gamma-ray device through an Indian gamma cell. The irradiated spores were kept in the dark to prevent any photoreaction. The treated and untreated spores were inoculated onto PDA plates by the serial dilution method and incubated at $25^{\circ} \mathrm{C}$ for 3 days. Fifty single colonies were selected according to the morphological variation in the dark preserved at $4^{\circ} \mathrm{C}$. The selected colonies were inoculated into MPA production medium and incubated for 10 days at $25^{\circ} \mathrm{C}$. The MPA productivity of the selected mutants was quantitatively estimated, and the highest producer mutant over wild type was used for stability examination. The stability of each mutant was tested for four generations according to Luthra et al. [33], and the three most stable MT strains were selected for our study.

\subsection{Optimization of fermentation conditions}


The fermentation conditions, including culture media, incubation temperature, initial $\mathrm{pH}$ values, and fermentation periods, were screened for maximum production of MPA by both the WT strain, $P$. arizonense HE-MPw1, and the highest producer MT, $P$. arizonense HE-MPM1. Six types of broth cultures (PD, CDYE, YES, LCG150, MES, and YPD) were screened for optimum production of MPA. The incubation time was selected between 10 and 21 days, the tested temperatures were adjusted in the ranges of 20 and $40{ }^{\circ} \mathrm{C}$, and the $\mathrm{pH}$ values were adjusted in the ranges of $\mathrm{pH} 2$ - 8 using citrate phosphate buffer

[34]. One milliliter of approximately $10^{7}$ freshly prepared 5-day-old spore suspensions of the WT and MT strains was inoculated into $50 \mathrm{ml}$ of sterilized MPA producer medium and incubated under selected conditions according to the experimental design. At the end of the incubation time, the amount of MPA was evaluated.

\subsection{Nucleic acid extraction}

Genomic DNA was extracted using the CTAB method as mentioned above. RNA was extracted by the Triazole reagent protocol (Invitrogen, Carlsbad, CA, USA) according to the manufacturers' instructions. The extraction protocol was modified with some additional steps according to Sah et al. [35]. The RNA pellet was dissolved in $60 \mu$ of autoclaved DEPC-treated water and stored at $-20^{\circ} \mathrm{C}$ until use. The primers of the MPA biosynthesizing gene cluster that were used in q-RTPCR analyses were designed from the coding sequence of the MPA gene cluster (mpaA, mpaC, mpaF, mpaG and $\mathrm{mpaH}$ ) of the $P$. roqueforti and $P$. brevicompactum genomes.

\subsection{Bioinformatic analysis of the MPA gene cluster and primer design}

The MPA gene cluster was identified in the BGC, antiSMASH, and MIBiG databases through the secondary metabolite bioinformatics portal https://mibig.secondarymetabolites.org/. The high conservation between the MPA biosynthesizing genes $m p a F, m p a C, m p a G$ of $P$. brevicompactum and their orthologous genes in the $P$. arizonense genome encouraged us to scan the whole similar putative protein responsible for MPA production in the genome of $P$. arizonense using BlastX, BlastP and BlastN databases. These searches were carried out using the online web link http://blast.ncbi.nlm.nih.gov. The primers for the cluster gene of MPA biosynthesis were designed from P. brevicompactum MIBiG accession BGC0000104 and NCBI GenBank:

HQ731031.1. The primers that gave weak amplification were redesigned from the corresponding putative region of $P$. arizonense (strain: CBS 141311). All primers were designed by the Primer 3 plus program http://primer3plus.com/cgi-

bin/dev/ primer3plus.cgi and are listed in Table (1). The primers were tested for amplification of their corresponding fragments by amplification of conventional PCR analysis. The amplicons were identified using agarose gel electrophoresis, and primers that gave potent amplification were used to continue the molecular analysis of the MPA gene cluster. The designed primers were purchased from Sigma-Aldrich (St. Louis, MO).

\subsection{Detection of the MPA gene cluster in the $P$. arizonense genome using conventional PCR analysis}

The wild type, $P$. arizonense HEwt, and the three MPA producer mutants were inoculated into PD broth and incubated at $25^{\circ} \mathrm{C}$ for 5 days under shaking conditions at $150 \mathrm{rpm}$. MPA was determined as shown previously, and mycelial wet mats were used for DNA extraction. Conventional PCR amplification of the MPA gene cluster from the gDNA of wild-type and mutant strains was carried out using the designed oligonucleotide primers shown in Table (1). PCR was performed in a final volume of $20 \mu$ at the following reagent concentrations: $4 \mu \mathrm{l}$ of $5 \times$ Phusion HF Green buffer, $0.4 \mu \mathrm{l}$ of $10 \mathrm{mM}$ dNTPs, 10 pmol of forward and reverse primers $(1 \mu \mathrm{l}$ each), Phusion $0.2 \mu \mathrm{l}$ of HF DNA polymerase enzyme at $2 \mathrm{U} / \mu \mathrm{l}, 2 \mu \mathrm{l}$ of template DNA (approximately $10 \mathrm{ng}$ ), and the total volume of the PCR mixture was adjusted to $20 \mu \mathrm{l}$ with nuclease-free water. PCR amplification included an initial denaturation step at $98^{\circ} \mathrm{C}$ for $30 \mathrm{~s}$, followed by 35 cycles of $98^{\circ} \mathrm{C}$ for $10 \mathrm{~s}$, an annealing step for $15 \mathrm{~s}$ at $60{ }^{\circ} \mathrm{C}$, an extension step for $20 \mathrm{~s}$ at $72{ }^{\circ} \mathrm{C}$, and a final extension for $5 \mathrm{~min}$ at $72^{\circ} \mathrm{C}$. The PCR products were analyzed by $1 \%$ agarose gel electrophoresis in $1 \times$ TEA buffer at room temperature. For gel analysis, $5 \mu \mathrm{L}$ of the PCR products were loaded in each gel slot. A 100 bp DNA Ladder (Qiagen) was used to determine DNA fragment size. The gel was photographed by a gel documentation system.

\subsection{Gene expression, sequencing, and phylogenetic analysis}

Quantitative real-time PCR analysis was used to estimate the gene expression of the MPA gene cluster in $P$. arizonense. The wildtype and producer mutant strains were inoculated in PD broth and incubated for 5 and 10 days under favorable conditions for MPA production. After the incubation time, mRNA was extracted from the fungal mats, and cDNA of the MPA gene cluster was 
transcribed using reverse transcriptase enzyme using the same primers mentioned previously. The primers were designed for gene coding sequences for partial amplification of cDNA. Primers were utilized in a $25-\mu \mathrm{L}$ reaction containing $0.25 \mu \mathrm{L}$ Verso Enzyme Mix (including RNase inhibitor), $12.5 \mu \mathrm{L}$ 2× Quanti Tect SYBR Green PCR Master Mix (Qiagen), $1.25 \mu \mathrm{L}$ RT enhancer (Thermo Scientific), $0.5 \mu \mathrm{L}$ of each primer (10 pmol/ $\mu \mathrm{L}), 2.5 \mu \mathrm{L} \mathrm{cDNA}$ template and $6.5 \mu \mathrm{L}$ water. The reaction was performed in a Strata-gene MX3005P real-time PCR machine. PCR conditions were as follows: reverse transcription $50{ }^{\circ} \mathrm{C}$ for 30 min, initial denaturation for $5 \min 94^{\circ} \mathrm{C}$, followed by 40 cycles of secondary denaturation at $94^{\circ} \mathrm{C}$ fo $15 \mathrm{~s}$, annealing at $54{ }^{\circ} \mathrm{C}$ for $1 \mathrm{~s}$, and extension at $72{ }^{\circ} \mathrm{C}$ for $45 \mathrm{~s}$, followed by 1 cycle for dissociation curve analysis of denaturation at $94{ }^{\circ} \mathrm{C}$ for 1 min, annealing at 54 ${ }^{\circ} \mathrm{C}$ for $1 \mathrm{~min}$, and final denaturation at $94^{\circ} \mathrm{C}$ for $1 \mathrm{~min}$. Amplicon size for each primer pair was verified by gel electrophoresis. The $\beta$-actin gene was used as a housekeeping gene through two primers: ACT 512-F (5' ATG TGC AAG GCC GGT TTC GC 3') and ACT 783-R (5' TAC GAG TCC TTC TGG CCC AT 3') [36]. The RT-PCR data were analyzed by IQ5 optical system software (BioRad, Hercules, CA). The threshold cycles were calculated using the PCR baseline subtracted mode, and the amplification efficiency for each gene amplified from wild-type and mutant strains of $P$. arizonense was estimated. CT values and amplification curves were calculated using Stratagene MX3005P software (Stratagene, La Jolla, CA). The CT value of the $\beta$-actin gene, derived from the amplicons, was used as a reference for normalization. To determine the variation in the expression of the MPA gene cluster from the mutant strains, the CT value of each sample was compared with that of the positive control (wild-type strain) according to the $\mathrm{B} \Delta \Delta \mathrm{Ct}^{\wedge}$ method reported by Yuan et al. [37] using the following proportion (2- $\Delta \Delta \mathrm{ct}$ ). $\Delta \Delta \mathrm{Ct}=\Delta \mathrm{Ct}$ reference $-\Delta \mathrm{Ct}$ target, $\Delta \mathrm{Ct}$ target $=\mathrm{Ct}$ control $-\mathrm{Ct}$ treatment and $\Delta \mathrm{Ct}$ reference $=\mathrm{Ct}$ control $-\mathrm{Ct}$ treatment. enhancer (Thermo Scientific). The purified PCR products of the MPA gene cluster amplified from the wild-type strain of $P$. arizonense were sequenced in the forward and reverse directions on an Applied Biosystems 3130 Automated DNA Sequencer (ABI, 3130, Applied Biosystems, Foster City, CA) using a ready reaction Bigdye Terminator V3.1 cycle sequencing kit (Perkin-Elmer/Applied Biosystems; Cat. No. 4336817). A BLAST ${ }^{\circledR}$ analysis, Basic Local Alignment Search Tool [38], was initially performed to establish sequence identity to GenBank accessions. The retrieved sequences of all genes were annotated and aligned through the NCBI database using the online website link http://blast.ncbi.nlm.nih.gov. The completely annotated sequences were registered in the GenBank database under the accession numbers listed in Table (2). Multiple sequence alignments of the deduced DNA and proteins were analyzed using the ClustalW program in MegX software, and phylogenetic analysis of both protein and DNA sequences was carried out. The evolutionary history was inferred using the neighbor-joining method [39]. The percentage of replicate trees in which the associated taxa clustered together in the bootstrap test (1000 replicates) is shown next to the branches. The tree is drawn to scale, with branch lengths (next to the branches) in the same units as those of the evolutionary distances used to infer the phylogenetic tree. The evolutionary distances were computed using the p-distance method and are in units of the number of amino acid differences per site. The analysis involved 5 amino acid sequences. All ambiguous positions were removed for each sequence pair. There were a total of 2502 positions in the final dataset. Evolutionary analyses were conducted in MEGA7 [40]. The conserved regions of all MPA gene clusters were analyzed for their related protein families in the conserved domain database https://www.ncbi.nlm.nih.gov/cdd/.

\subsection{Statistical analysis}

Statistical analysis was performed using SPSS version 25 (IBM Corp., Armonk., NY). Data were presented as the mean \pm standard deviation (SD). For all experiments, a minimum of 3 biological replicates was used. The paired samples t test was used for the intramutant comparison (between after 5 days and 10 days of incubation), while one-way analysis of variance (ANOVA) with post hoc pairwise comparisons adjusted by Tukey's post-test was performed for the evaluation of the difference between mutants in each gene. $P$ values less than 0.05 were considered statistically significant.

\section{Results}

\subsection{Mycological Survey and MPA Production}

Between thirty-six fungal strains isolated from different types of refrigerated cheeses, an MPA producer strain showing high similarity with $P$. arizonens was selected in this study as a new producer strain for MPA. Morphological identification indicated that this species belongs to section Canescentia, and molecular analysis of the ITS region confirmed its close relation to $P$. arizonens. Phylogenetic computation according to marker genes proved the grouping of this strain within section Canescentia, 
and approximately $98.5-99 \%$ similarity was detected with other related strains of $P$. arizonens deposited in the GenBank database (Fig. 1). Based on morphological and molecular analyses, the isolated strain was named $P$. arizonens HE-MAwt, and its ITS sequence was submitted to the GenBank database under the accession number MT355884.

\subsection{Characterization of MPA}

The produced compound was initially identified by TLC and then quantified by HPLC analysis in front of the authentic compound. The results presented in Fig. (2) indicated the presence of blue fluorescence spots after exposure of the TLC plate to ammonium vapor in front of the authentic standard compound. The Rf value of the standard solution was equal to the compound separated by our organism. Quantitative determination of MPA produced by wild-type and mutant strains of $P$. arizonense was performed by HPLC analysis, as shown in Fig. (3).

\section{Overproduction of MPA by mutagenesis of $P$. arizonense and optimization of fermentation conditions}

Three mutant strains of $P$. arizonense, namely, HE-MPM1, HE-MPM2, and HE-MPM3, were selected as stable overproducer mutants to produce MPA. The production of MPA was estimated after each incubation time for four respective generations, as shown in Table (3). The results indicated that the selected three mutants retained their mutation for 4 generations without significant changes. The MPA amounts produced by MT1, MT2, and MT3 were $11.82 \pm 0.174,9.231 \pm 0.178$, and 8.79 \pm 0.168 , respectively, while the amount produced by the wild-type strain was $5.457 \pm 0.174$. These results indicated that MPA production by M1, M2, and M3 was increased by 2.1-, 1.7-, and 1.6-fold, respectively, compared with the wild-type strain.

To reach the highest amounts of MPA by our experimental strains, the upstream processing conditions for the production of MPA by WT and MT strains of $P$. arizonense were optimized (Fig. 4). PD broth medium was the best culture medium for maximum production of MPA by wild-type HE-MPWt and mutant strain HE-MPM1 of $P$. arizonense $(597.449 \pm 11.915$ and $1202.620 \pm 12.358$ $\mu \mathrm{g} / 100 \mathrm{ml}$, respectively, as shown in Fig. $4_{\mathrm{a}}$ ). Optimizing the fermentation conditions was extended to investigate the optimum incubation time for MPA production. The obtained results from Figure $\left(\mathbf{4}_{\mathbf{b}} \mathbf{)}\right.$ revealed that MPA appeared in the culture filtrate of both the HE-MPWt and HE-MPM1 strains of $P$. arizonense after 5 days of incubation $\left(3.441 \pm 0.943\right.$ and $5.775 \pm 0.252 \mu \mathrm{g} \mathrm{ml}^{-1}$, respectively), and then it was increased by increasing the incubation time until reaching its maximum value $(9.032 \pm 0.12$ and $17.99 \pm 0.094 \mathrm{~g} \mathrm{ml}^{-1}$ ) after 15 days of incubation. The production of MPA by the two experimental strains was also greatly affected by the initial $\mathrm{pH}$ value of the culture medium (Figure $4_{\mathrm{c}}$ ). The results showed that MPA production by $P$. arizonense HEMPWt and $P$. arizonense HE-MPM1 increased gradually by increasing the $\mathrm{pH}$ value of the culture medium, reaching maximum values $\left(9.0 \pm 0.27\right.$ and $17.98 \pm 0.285 \mathrm{\mu g} \mathrm{ml}^{-1}$, respectively) at pH 6 after 15 days of incubation at $25^{\circ} \mathrm{C}$. After incubation of both the wild-type and mutant strains at $10,15,20,25,30$, and $35^{\circ} \mathrm{C}$ for 10 days, the optimum incubation temperature for maximum production of MPA by both the $P$. arizonense HE-MPWt and $P$. arizonense HE-MPM1 strains $(5.974 \pm 0.31$ and $12.1 \pm 0.2404 \mu \mathrm{g}$ $\mathrm{ml}^{-1}$, respectively) was recorded at $25^{\circ} \mathrm{C}$, whereas the two tested strains failed to produce MPA at $10^{\circ} \mathrm{C}$ and $35^{\circ} \mathrm{C}$ (Fig. $4_{d}$ ). In general, there were significant differences in MPA production by the wild-type and mutant strains under all tested environmental conditions according to independent samples t tests $(P \leq 0.05)$.

\section{Molecular analysis of the MPA biosynthesizing gene cluster in WT and MT strains of P. arizone}

\subsubsection{Conventional PCR analysis}

The WT-type strains of $P$. arizonense HE-MPwt and the MPA producer mutant strains ( $P$. arizonense HE-MPM1, MPM2, and MPM3) were inoculated into potato dextrose culture broth medium and incubated at $25^{\circ} \mathrm{C}$ for 5 days. The MPA was evaluated in the medium as shown previously, and the fungal mats were used for DNA extraction. PCR analysis was carried out according to the oligonucleotide primers shown in Table (1) to amplify the MPA producer genes ( $m p a F, m p a C, m p a A, m p a G, m p a H, m p a E$, $m p a D$ and $m p a B$ ) from the genome of all experimental strains. Conventional PCR analysis was used to detect the presence of all mentioned genes in the fungal genome according to the expected fragments of each gene, which depend on the designed forward and reversed primers. Different primers of the MPA gene cluster, designed from $P$. brevicombactim, were tested for their ability to be amplified from $P$. arizonense. The primers $\mathrm{mpaC}, \mathrm{mpaF}$, and $\mathrm{mpaG}$ succeeded in amplification from $P$. arizonense. The primers $m p a B, m p a D$, and $m p a E$ failed to amplify after several trials, whereas the amplification of $m p a A$ and $m p a H$ was very 
weak. Therefore, other primers were designed from the $P$. arizonense (strain: CBS 141311) genome to test the amplification of the orthologous genes $m p a A$ and $m p a H$. The produced amplicons were separated by agarose gel electrophoresis, and the size of each amplicon was calculated according to the DNA marker. Fig. S. (1) shows the fragment sizes of $m p a A, m p a C m p a F, m p a G$, and $\mathrm{mpaH}$, which were $288,283,258,258$, and $251 \mathrm{bp}$, respectively, in both wild-type and mutant strains. According to these results, molecular studies were extended to the five amplified genes to analyze their expression values in mutant and wild-type strains.

\subsubsection{Sequencing and phylogenetic analyses of the MPA gene cluster}

The amplicons resulting from cDNA amplification of the MPA genes (Fig. S. 2) were sequenced in the forward and reverse directions using the designed primers listed in Table (1). The obtained sequences of all amplified genes were aligned against the more related genes deposited in the GenBank database using multiple sequence alignment search tools. The blast alignment and bioinformatic analysis of the MPA gene cluster revealed that all retrieved gene sequences showed $96-97 \%$ similarity with the related hypothetical protein of $P$. arizonense submitted in the GenBank database and $82-96 \%$ similarity with the orthologous genes of MPA biosynthesizing gene clusters of both $P$. brevicopmactum and $P$. roqfourti. mpaA showed $96 \%$ similarity with the orthologous $m p a A$ gene of $P$. roqueforti (KU234531.1) strain PTX. PR and $96 \%$ similarity with homologous putative hypothetical protein (PENARI_C010G07427) of $P$. arizonense(XM_022632298.1). Additionally, mpaC showed $93.7 \%$ similarity with the hypothetical protein (PENARI_C010G07355) of $P$. arizonense(XM_022632294.1) and 82.05 with mpaC of P. brevicompactum (HQ731031.1), which is one of the gene clusters of mycophenolic acid biosynthesis. The mpaF gene showed $96.25 \%$ similarity with the hypothetical protein (PENARI_C010G04864) of $P$. arizonense (XM_022632233.1) partial mRNA and 84.017\% similarity with mpaF of $P$. brevicompactum (HQ731031.1), which is one of the gene clusters responsible for mycophenolic acid biosynthesis. The $\mathrm{mpaG}$ gene detected $97.29 \%$ similarity with its related hypothetical protein (PENARI_c005G09215) of $P$. arizonense (XM_022629943.1) and 82.44\% similarity with the mycophenolic acid biosynthesis gene mpaG of $P$. roqueforti strain PTX.PR.27 (KU234531.1). mpaH showed high similarity (98.85\%) with the related hypothetical protein (PENARI_c010G08752) of $P$. arizonense (XM_022632342.1). The retrieved sequences of the MPA gene cluster, $m p a A, m p a C, m p a F, m p a G$, and $m a p H$ in $P$. arizonense HE-MPwt were registered in the GenBank database under the accession numbers MT786725, MT786724, MT786723, MT786726, and MT797806, respectively (Table 2). A proposed map of the MPA gene cluster in $P$. arizonense compared with the map of the MPA gene cluster in P. brevicompactum (HQ731031.1), retrieved from the MIBiG database, is represented in Fig. (5). The diagram shows the presence of five genes in the $P$. arizonense genome that could be responsible for MPA biosynthesis in $P$. arizonense. Phylogenetic analysis of these genes confirmed their close relation to the orthologous genes in both $P$. brevicompactum and $P$. roqueforti. All genes were more related to the homologous genes in $P$. arizonense registered in the GenBank database, as shown in Fig. (6). The amino acid sequences of the putative proteins also showed high similarity with other orthologous proteins of MPA in both P. brevicompactum and P. roqueforti (Fig. 7), and their conserved regions present in other homologous strains were detected in Fig. (8).

\subsubsection{Quantitative real-time reverse transcription (qRT-PCR) and gene expression analysis of the MPA gene cluster}

The RT-PCR results were analyzed with iQ 5 optical system software (Bio-Rad) using the PCR baseline subtracted mode. The threshold cycle was calculated for all samples, and the amplification efficiency for each gene amplified from $P$. arizonense (WT and MT strains) was determined. The threshold cycle of all genes, in addition to the housekeeping gene (B. actin gene), of $P$. arizonense (WT strain HE-MPwt and mutant strains MT1, MT2, and MT3) after $5 \mathrm{~d}$ and $10 \mathrm{~d}$ of incubation time are shown in Table (4) and Fig. (9). The wild-type strain was used as an endogenous control, and the B-actine gene was used for normalization as a housekeeping gene. Table (4) shows the expression of the MPA gene cluster, mpaA, mpaC, mpaF, mpaG and mpaH in MPA over producer mutant strains after 5 and 10 days of incubation. The obtained results recorded a significant increase in gene expression of all analyzed mycophenolic acid gene clusters in the three tested mycophenolic acids over producer mutants over the wild-type strain of $P$. arizonense. It was observed that the transcription value of the MPA gene cluster in mutant strain MT3 was the highest compared to the other mutant strains. The transcription values of $m p a A, m p a C, m p a F, m p a G$ and $m p a H$ in mutant strain MT3 were 1.5801, 1.3755, and 0.8766 after 5 days and 1.484-, 8.4561-, 5.656-, 3.0738-, and 4.626-fold higher than those in the wild-type strain after $10 \mathrm{~d}$ of incubation, respectively. It was observed that the gene expression of $m p a C, m p a F$, $m p a H$, and $m p a G$ was significantly increased according to the incubation time, and these increments corresponded to the

Page 8/22 
production of MPA, where its amount doubled after $10 \mathrm{~d}$ of incubation. The expression values of $m p a C$ and $m p a F$ were significantly higher than those of the other genes according to $t$ test analysis, where the $p$ value was lower than 0.05 . The expression values of $m p a C$ and $m p a F$ were the highest in all mutants, followed by $m p a H$ and mpaG, whereas the expression value of $m p a A$ was the lowest at all. It was also noticed that the expression of the MPA gene cluster in the mutant strain MT1 was higher than that of MT2 and MT3 after 5 and 10 days of incubation. The gene expression of the mycophenolic acid gene cluster was correlated with the production of MPA, where the mutant strain MT1 was the highest producer strain for MPA and the production of MPA significantly increased after 10 days of incubation. The recorded results confirmed the potential roles of the five genes mpaA, mpaC, mpaG, mpaF, and mpaH in the biosynthesis process of MPA in $P$. arizonense.

\section{Discussion}

Penicillium is a vital industrial unit for the biosynthesis of many chemically and structurally diverse secondary metabolites, including significant pharmaceutical compounds [3]. Through this study, we isolated a new strain of $P$. arizonense from refrigerated Mozzarella cheese, and it was found to be a strong producer of MPA when it was grown in submerged PD broth culture. The morphological identification and marker gene analysis of rRNA confirmed the highest similarity of our isolate with $P$. arizonense CBS141311. The genus Penicillium is a strong producer strain for various secondary metabolites, and among MPA producers, only certain strains of fungi of Penicillium named P. brevicompactum (also known as $P$. stoloniferum), $P$. paxilli, $P$. olivicolor, $P$. canescens (also known as $P$. raciborskii), $P$. roqueforti, and $P$. viridicatum were identified [41, 42]. Large numbers of secondary metabolites, such as tryptoquivalines, pyripyropenes, austalides, fumagillin, pseurotin $A$, xanthoepocin, and curvulinic acid, were investigated in the cell extract of $P$. arizonense [3]. The discovery of additional bioactive compounds in the bioprocess extract of $P$. arizonense is still under investigation. The identification of such bioactive secondary metabolites displays a wide range of strong industrial and biotechnological applications for $P$. arizonense. The use of mutations to improve several microorganisms for the overproduction of industrial products has been applied for over 50 years and is still accepted as a valuable agent for the improvement of different microbial strains. Through the exposure of wild-type $P$. arizonense to random mutagenesis by gamma irradiation, potential producer mutants for MPA were obtained. We succeeded in isolating three stable mutants of $P$. arizonense that had the ability to produce double the amount of MPA compared with the wild-type strain. This result indicated the technological modification of our isolate and mutagenesis of the MPA gene cluster. Such a mutagenic strain could minimize the cost of the manufacturing processes and enhance the productivity of MPA. The improvement of MPA production was previously investigated by exposing $P$. brevicompactum to 250 Gy of gamma radiation, which led to an increase in MPA production productivity by $25 \%$ [33]. Gamma rays may cause various mutations in the gene cluster responsible for secondary metabolite biosynthesis, leading to an increase or decrease in their production [43]. Because $P$. arizonense is considered a new producer strain for MPA, the ecophysiological parameters for its production must be optimized to achieve maximum productivity. The incubation temperature and time were effective factors in the production activity of MPA by both wild-type and mutant strains. Generally, similar to other secondary metabolites, the production of MPA was noticed to be increased during the stationary phase of fungal growth. MPA is a secondary metabolite, so its production was affected by the time of incubation, where the elongation of incubation time to 10 and 15 days enhanced the productivity of our experimental strains. Similarly, Vinokurova et al. [44] (reported that MPA synthesis was dramatically concentrated during the stationary phase of growth after 10 days of incubation). Additionally, the initial $\mathrm{pH}$ value and the incubation temperature were critical factors affecting the production of MPA by P. arizonense. The highest production of MPA was observed when all fungal strains were grown on PD broth adjusted to initial pH 6 and incubated at $25^{\circ} \mathrm{C}$. Accompanied by our results, Patel et al. [45] recorded that the optimum culture conditions for maximum production of MPA were detected after incubation of $P$. brevicompactum for $12 \mathrm{~d}$ at $25^{\circ} \mathrm{C}$ using $\mathrm{pH} 5$ as an initial value.

Because many of the preferable compounds are naturally produced in considerable amounts, fungi have great potential as specific hosts for the biosynthesis of small molecules. The broad benefit in fungi has led to hole sequencing of numerous fungal genomes. This number is expected to dramatically increase in the upcoming years [46]. Information concerning the molecular basis of MPA biosynthesis in P. arizonense would be very helpful for both the potential production of MPA and the control of its contamination in food products; however, there is no previous information about the biosynthetic pathway. Through this study, five orthologous genes of the MPA cluster were identified in the $P$. arizonense genome, namely, $m p a A, m p C, m p a F, m p a G$, and $m p a H$. The genes $m p a A$, which encodes a putative prenyltransferase; $m p a C$, which encodes a polyketide synthase; $m p a D E$, which 
encodes a natural fusion of a cytochrome P450 domain and a hydrolase domain; mpaF, which encodes a protein with high similarity to inosine-5'-monophosphate dehydrogenase (IMPDH); $m p a G$, which encodes an 0-methyltransferase; and $m p a H$, which encodes an oxidative cleavage enzyme, were identified as gene clusters for MPA biosynthesis in the $P$. brevicompactum genome. The $\mathrm{mpaC}$ gene is responsible for the biosynthesis of 5-methylorsellinic acid (5-MOA), which is the initial step in MPA synthesis. The following conversion of 5-MOA to 4,6-dihydroxy-2-(hydroxymethyl)-3-methylbenzoic acid and 5,7-dihydroxy-4methylphthalide (DHMP) was performed by the enzyme MpaDE. The final step in the biosynthesis process is completed by $M p a G$ (the putative 0-methyl transferase), which stimulates the methylation of demethylmycophenolic acid (DMMPA) to form MPA. The gene cluster encoding MPA was recently investigated in both $P$. brevicompactum [6] and $P$. roqueforti $[22,47]$. $P$. arizonense is defined as one of a group that belongs to Penicillium section Canescentia and contains a large number of genes participating in lipid metabolism and secondary metabolite production. Sequencing analysis of the $P$. arizonense genome revealed that it was assembled into $33.7 \mathrm{Mb}$ containing 12,502 predicted genes [3]. Additionally, 62 putative biosynthetic gene clusters involved in secondary metabolite biosynthesis were identified in its genome. To date, the putative genes that participated in the $P$. arizonense genome have not been completely annotated, and their phenotypic action is still under investigation. It was previously investigated whether $P$. arizonense contains gene clusters responsible for austalide (meroterpenoid) production. Mycophenolic acid is an important compound related to meroterpenoids that is composed of a terpene-derived side chain and an acetatederived phthalide nucleus [48]. This phthalide structure is also present in the austalides, so it is likely that austalides and mycophenolic acid have identical biosynthetic gene clusters. Orthologs to mpaC, mpaD, and mpaA genes evolving in the MPA biosynthesis cluster of $P$. brevicompactum were found in the $P$. arizonense genome [3]. This report agrees with our investigation, where a homologous partial sequence of 5 genes with locus tags, PENARI_C010G07427, PENARI_c010G07355, PENARI_C010G04864, PENARI_C005G09215, and PENARI_C010G08752, were annotated in the $P$. arizonense genome, and they were found to be orthologs to the MPA gene cluster $m p a A, m p a C, m p a F, m p a G$, and $m p a H$, respectively, in $P$. brevicompactum. Gene expression analysis of these genes in all MPA over producer mutants showed a highly significant fold increase over the wild type after incubation times of 5 and 10 days. Additionally, the expression values of all genes were higher after $10 \mathrm{~d}$ than after $5 \mathrm{~d}$ of incubation. This result agrees with the physiological study of MPA production by mutant and wild-type strains of $P$. arizonense, where the amount of MPA was significantly higher in all mutant strains compared to wild-type and increased after $10 \mathrm{~d}$ of incubation compared to after $5 \mathrm{~d}$. The obtained results confirmed the vital role of these genes in the biosynthesis pathway of MPA and was considered an indication of the capability of the $P$. arizonenseHEwt strain to produce MPA in submerged culture. This is the first report concerning the potential of $P$. arizonense for MPA production and molecular annotation and expression of gene clusters that are responsible for MPA biosynthesis in its genome. This investigation could be a new platform for the industrial biosynthesis of this vital compound using a new producer species of Penicillium and considered a new annotation of a gene cluster shared in MPA biosynthesis in the P. arizonene genome.

\section{Conclusion}

We concluded from this study that the Penicillium group contains various species that have the capability to produce several important secondary metabolites. A new local strain of $P$. arisonense was isolated from refrigerated cheese and identified as $P$. arizonense HE-wt. This strain showed high productivity for MPA during its growth in PD broth. The production of MPA was forced by mutagenesis of the wild type and isolation of three stronger stable mutants for MPA production. The optimized conditions for maximum production of MPA by both mutant and wild type revealed that the growth of all strains on PD broth adjusted to $\mathrm{pH} 6$ and incubated at $25^{\circ} \mathrm{C}$ for $15 \mathrm{~d}$ were optimum for MPA production. The molecular basis for MPA production in $P$. arizonens was also investigated in our research. Through partial sequencing analysis of the MPA ortholog gene cluster, we identified five open reading frames of locus tags, PENARI_c010G07427, PENARI_c010G07355, PENARI_c010G04864, PENARI_c005G09215, and PENARI_c010G08752, that were orthologous to the MPA gene cluster $m p a A, m p a C, m p a F, m p a G$, and mpaH and could be responsible for MPA biosynthesis in $P$. arizonense. The functional and gene expression analyses of this cluster showed their importance in the biosynthesis of MPA by $P$. arizonense and suggested that three of them, namely, $m p a C, m p a F$, and $m p a G$, have an intensive role in the biosynthesis process. This is the first report about the identification of a new MPA producer strain belonging to section Canescentia and the investigation of an orthologous gene cluster for MPA biosynthesis in the $P$. arizonens genome. 


\section{References}

1. Visagie CM, Houbraken J, Frisvad JC, Hong S-B, Klaassen CHW, Perrone G, et al. (2014) Identification and nomenclature of the genus Penicillium. Stud Mycol.; 78:343-71.

2. Frisvad J.C., Smedsgaard J., Larsen TO, Samson R.A (2004) Mycotoxins, drugs and other extrolites produced by species in Penicillium subgenus Penicillium. Stud Mycol., 49:201-41.

3. Grijseels S., Nielsen J.C. Randelovic M., Nielsen J., Nielsen K.F., Workman M., Frisvad J.C. (2016) Penicillium arizonense, a new genome sequenced fungal species, reveals a high chemical diversity in secreted metabolites. Scientific Reports, 6:35112, DOI: 10.1038/srep351121.

4. Bentley, R. (2000) Mycophenolic acid: a one hundred year odyssey from antibiotic to immunosuppressant. Chem. Rev. 100:3801-3826.

5. Sadhukhan K., Ramana Murthy A.K., Ajaya Kumar M.V., Mohan R., Vandana E.V.S., Bhar G., Venkateswara Rao C. (1999) Optimization of mycophenolic acid production in solid-state fermentation using response surface methodology, J. Ind. Microbiol. Biotechnol. 22: 33-38.

6. Regueira T.B., Kildegaard K.R., Hansen B.G., Mortensen U.H., Hertweck C., Nielsen J. (2011) Molecular basis for mycophenolic acid biosynthesis in Penicillium brevicompactum. Appl Environ Microbiol.,77: 3035-3043. doi: 10.1128/AEM.03015-10.

7. Ismaiel A.A., Ahmed A.S, El-Sayed E.-S.R. (2014) Optimization of submerged fermentation conditions for immunosuppressant mycophenolic acid production by Penicillium roqueforti isolated from blue-molded cheeses: enhanced production by ultraviolet and gamma irradiation, World J. Microbiol. Biotechnol. 30 2625-2638.

8. Puel O., Tadrist S., Galtier P., Oswald I.P., Delaforge M. (2005) Byssochlamys nivea as a source of mycophenolic acid, Appl. Environ. Microbiol. 71: 550-553.

9. Vinci M.C., Go E., Tarnawsky S.P., Shelley W.C., Banno K., Lin Y., Gil C-H, Blue EK, Haneline L.S., Neil KM, Yoder M.C. (2018) Mycophenolic acid induces senescence of vascular precursor cells. PLoS One 13(3):e0193749.

10. Shaw L.M., Figurski M., Milone M.C., Trofe J., Bloom R.D. (2007) Therapeutic drug monitoring of mycophenolic acid. Clin J Am Soc Nephrol, 2(5):1062-1072.

11. Abd Rahman A.N., Tett SE, Staatz CE. (2013) Clinical pharmacokinetics and pharmacodynamics of mycophenolate in patients with autoimmune disease. Clin Pharmacokinet; 52(5):303-331.

12. Yin Y., Wang Y., Dang W., Xu L., Su J., Zhou X., W. Wang, Felczak K., van der Laan L.J., Pankiewicz K.W. (2016), Mycophenolic acid potently inhibits rotavirus infection with a high barrier to resistance development, Antivir. Res. 133 41-49.

13. To K.K., Mok K.Y., Chan A.S., Cheung N.N., Wang P., Lui Y.M., Chan J.F., Chen H., Chan K.H., Kao R.Y. (2016) Mycophenolic acid, an immunomodulator, has potent and broad-spectrum in vitro antiviral activity against pandemic, seasonal and avian influenza viruses affecting humans, J. Gen. Virol. 97 1807-1817.

14. Shen L., Niu J., Wang C., Huang B., Wang W., Zhu N., Deng Y., Wang H., Ye F., Cen S. (2019), High-throughput screening and identification of potent broadspectrum inhibitors of coronaviruses, J. Virol. 93 e00023-00019.

15. Kato F., Matsuyama S., Kawase M., Hishiki T, Katoh H., Takeda M. (2020) Antiviral activities of mycophenolic acid and IMD0354 against SARS-CoV-2, Microbiology and Immunology, 64:635-639.

16. Dowran R., Nabavi S.F., Habtemariam S., Banach M., et al. (2020) Various interferon (IFN)-inducible transmembrane (IFITM) proteins for COVID-19, is there a role for the combination of mycophenolic acid and interferon? Biochimie 177:50-52.

17. Northolt, M. D., Frisvad, J. C., Samson, R. A. (1995). In R. A. Samson, E. S. Hoekstra, \& Oorschot, Introduction to su` foodborne fungi. Cantraalbureau voor Schimmelcutures CAN: 243-250.

18. Geisen, R., Cantor, M. D., Hansen, T. K., Hozapfel, W. H., \& Jakobsen,M. (2001). Characterization of Penicillium roqueforti strains used as cheese starter cultures by RAPD typing. International Journal of Food Microbiology, 65, 183-191.

19. Zambonin C.G., Monaci L., Aresta A. (2002) Analytical, Nutritional and Clinical Methods Solid-phase microextraction-highperformance liquid chromatography and diode array detection for the determination of mycophenolic acid in cheese. Food Chemistry 78: 249-254. 
20. Hansen B.G., Mnich E, Nielsen K.F., Nielsen J.B., Nielsen M.T., Mortensen U.H., et al (2012) Involvement of a natural fusion of a cytochrome P450 and a hydrolase in mycophenolic acid biosynthesis. Appl Environ Microbiol.; 78: 4908-4913. DOI: 10.1128/AEM.07955-11 PMID: 22544261.

21. Zhang W., Cao S., Qiu L., Qi F, Li Z., Yang Y, et al. (2015) Functional characterization of MpaG', the O-methyltransferase involved in the biosynthesis of mycophenolic acid. Chembiochem.; 16: 565-569. doi:10.1002/cbic.201402600 PMID: 25630520 .

22. Del-Cid A., Gil-Durán C., Vaca I., Rojas-Aedo J.F., García-Rico R.O., Levicán G., Chávez, R. (2016) Identification and functional analysis of the mycophenolic acid gene cluster of Penicillium roqueforti. PLOS One 11, e0147047.

23. Hansen B.G., et al. (2011) A new class of IMP dehydrogenase with a role in self-resistance of mycophenolic acid producing fungi. BMC Microbiol. 11:202. DOI: 10.1186/1471-2180-11-202.

24. Smith C.M., Fontenelle L.J., Muzik H., Paterson A.R., Unger H., Brox L.W., Henderson J.F. (1974) Inhibitors of inosinate dehydrogenase activity in Ehrlich ascites tumor cells in vitro. Biochem. Pharmacol. 23:2727-2735.

25. Raper K.B., Fennell D.I. (1965) The genus Aspergillus. Williams \& Wilkins, Baltimore.

26. Pitt Jl, Hocking AD (1997) Fungi and food spoilage, 2nd edn. Blackie Academic and Professional, London.

27. Lee S.B., Milgroom, M.G., Taylor J.W. (1988) A rapid, high yield mini-prep method for isolation of total genomic DNA from fungi. Fungal Genet Newsl 35, 23-24.

28. Wu Z.H., Wang T.H., Huang W., Qu Y.B. (2001) A simplified method for chromosome DNA preparation from filamentous Fungi. Mycosystema, 20: 575-577.

29. White TJ, Bruns T, Lee S, Taylor J (1990) Amplification and direct sequencing of fungal ribosomal RNA genes for phylogenetics. In: Innis MA, Gelfand DH, Sninsky JJ, White TJ (eds) PCR Protocols: a guide to methods and applications. Academic Press, New York, pp 315-322.

30. Sambrook J, Russell D (2001) Molecular Cloning: A Laboratory Manual, 3rd edn. Cold Spring Harbor, NY: Cold Spring Harbor Laboratory Press.

31. Tamura K, Nei M, Kumar S (2004) Prospects for inferring very large phylogenies by using the neighbor-joining method. Proc Natl Acad Sci USA 101(3):11030-11035.

32. Queener SW, Nash III CH (1978) Procedure for obtaining Penicillium species mutants with improved ability to synthesize mycophenolic acid. US Patent 4, 115,197.

33. Luthra U, Khadpeka S, Trivedi, Kumar, Singh N, Tripathi (2014) Induced mutation by gamma radiation of Penicillium brevicompactum to enhance production of Mycophenolic acid. IJAST 4:952-957.

34. Malik C.P. and Singh M.B. (1980). Plant Enzymology and Histo-Enzymology: A text manual. Kalyani Publications, New Delhi/Ludhiana. pp. 434.

35. Sah S.K., Kaur G., Kaur A. (2014) Rapid and Reliable Method of High-Quality RNA Extraction from Diverse PlantsAmerican Journal of Plant Sciences 5(21):3129-3139.

36. Carbone I., and Kohn L. M. (1999) A method for designing primer sets for speciation studies in filamentous ascomycetes. Mycologia 91, 553-556. DOI: 10.2307/3761358.

37. Yuan J.S., Reed A., Chen F., Stewart J.R. (2006) Statistical analysis of realtime PCR data. BMC Bioinformatics 7:85

38. Altschul S.F., Gish W., Miller W., Myers E.W., Lipmanl D.J. (1990) Basic local alignment search tool. J Mol Biol 215:403-410.

39. Saitou N. and Nei M. (1987). The neighbor-joining method: A new method for reconstructing phylogenetic trees. Molecular Biology and Evolution 4:406-425.

40. Kumar S., Stecher G., and Tamura K. (2016). MEGA7: Molecular Evolutionary Genetics Analysis version 7.0 for bigger datasets.Molecular Biology and Evolution 33:1870-1874.

41. Engel G. and Teuber M. (1984) in Mycotoxins: Production, Isolation, Separation and Purification, Betina, V., Ed., Amsterdam: Elsevier, pp. 303-306.

42. Frisvad, J.C. and Filtenborg, O. (1989) Mycologia, 81 (6): 837-861. 
43. Ammar H.A., Srour A.Y. \& Ezzat S.M., Hoseny A.M. (2017) Identification and characterization of genes involved in kojic acid biosynthesis in Aspergillus flavus. Ann Microbiol (2017) 67:691-702, DOI: 10.1007/s13213-017-1297-8.

44. Vinokurova N. G., Ivanushkina N. E., Kochkina G. A., Arinbasarov M. U., Ozerskaya S. M. (2004) Production of Mycophenolic Acid by Fungi of the Genus Penicillium Link. Applied Biochemistry and Microbiology, 41 (1) 83-86. Translated from Prikladnaya Biokhimiya i Mikrobiologiya, 41 (1):95-98.

45. Patel G., Patil M.D., Soni S., Khobragade T.P., Chisti Y., Banerjee, U.C. (2016) Production of mycophenolic acid by Penicillium brevicompactum, A comparison of two methods of optimization, Biotechnology Reports, 11:77-85, https://doi.org/10.1016/j.btre.2016.07.003.

46. Wilson R. A., Talbot N. J. 2009. Fungal physiology: a future perspective. Microbiology 155:3810-3815.

47. Rojas-Aedo, J.F., Gil-Durán, C., Del-Cid, A., Valdés, N., Álamos, P., Vaca, I., García-Rico, R.O., Levicán, G., Tello, M., Chávez, R. (2017) The biosynthetic gene cluster for andrastin An in Penicillium roqueforti. Front. Microbiol. 8, 813.

48. Birch A. J., English R. J., Massy-Westropp R. A., and Smith H. (1957) Origin of the terpenoid structures in mycelianamide and mycophenolic acid. Mevalonic acid as an irreversible precursor in terpene biosynthesis. Proc. Chem. Soc. (Great Britain) 1957:233-234.

\section{Tables}

Table (1) Primer sequences of the MPA gene cluster designed for conventional and qRT-PCR analyses

\begin{tabular}{|c|c|c|c|c|c|}
\hline Target genes & Primer sequences & Amplicon length (bp) & $\mathrm{Tm}$ & Amplification & References \\
\hline \multirow[t]{2}{*}{ mpaA } & TAGGGTGGCTCGGACAAAATG & 288 & 60.3 & $+\mathrm{ve}$ & Current study \\
\hline & TCTTGCCCATTGATCGAAGC & & 58.8 & & \\
\hline \multirow[t]{2}{*}{ mpaC } & TGACACGCAGAGCATTTGAC & 283 & 59.1 & $+\mathrm{ve}$ & Current study \\
\hline & TCGACCAATTGTGTCCATGC & & 59.8 & & \\
\hline \multirow[t]{2}{*}{ mpaF } & TTGATACCCCTGTCACCAAGC & 258 & 60 & $+\mathrm{ve}$ & Current study \\
\hline & ACTTGGCCTTGAGCTCCTTG & & 60.3 & & \\
\hline \multirow[t]{2}{*}{ mpaG } & CCCATGACATCTTCACAACGC & 258 & 59.9 & $+\mathrm{ve}$ & Current study \\
\hline & АTCTCCAATCGGCCTCTGTTC & & 59.9 & & \\
\hline \multirow[t]{2}{*}{$\mathrm{mpaH}$} & TGGTTGATCGGCGAAGACAAG & 251 & 60.9 & + ve & Current study \\
\hline & TACTGAGTCGCCCATTGGAAAG & & 60.4 & & \\
\hline
\end{tabular}

Table (2) Accession numbers and full annotation of the MPA biosynthesizing gene cluster of the $P$. arizonense genome. Annotation was acquired from the NCBI database. 


\begin{tabular}{|c|c|c|c|}
\hline $\begin{array}{l}\text { Accession } \\
\text { number }\end{array}$ & $\begin{array}{l}\text { Standard } \\
\text { name }\end{array}$ & $\begin{array}{l}\text { Locus tag in } P . \\
\text { arizonense }\end{array}$ & Gene description \\
\hline MT786725 & $\mathrm{mpaA}$ & PENARI_c010G07427 & $\begin{array}{l}\text { Polyprenyl transferase; part of the gene cluster that mediates the } \\
\text { biosynthesis of mycophenolic acid }\end{array}$ \\
\hline \multirow[t]{2}{*}{ MT786724 } & $\mathrm{mpaC}$ & & polyketide synthase \\
\hline & & PENARI_c010G07355 & $\begin{array}{l}\text { catalyzing the synthesis of 5-methyl orsellinic acid, first step of } \\
\text { mycophenolic acid biosynthesis" }\end{array}$ \\
\hline MT786723 & $\mathrm{mpaF}$ & PENARI_c010G04864 & Inosine-5'-monophosphate dehydrogenase \\
\hline MT786726 & $\mathrm{mpaG}$ & PENARI_c005G09215 & $\begin{array}{l}\text { S-adenosylmethionine-dependent methyltransferase (SAM or AdoMet- } \\
\text { MTase), class I; AdoMet-MTases are enzymes that use S-adenosyl-L-- } \\
\text { methionine (SAM or AdoMet) as a substrate for methyltransfer, creating } \\
\text { the product S-adenosyl-L-homocysteine (AdoHcy) }\end{array}$ \\
\hline MT797806 & mpaH & PENARI_c010G08752 & alpha/beta hydrolases \\
\hline
\end{tabular}

Table (3) Stability study of the mutant strains of $P$. arizonense grown on PD broth medium through four sequencing generations showing MPA amounts ( $\mu \mathrm{g} \mathrm{ml}^{-1}$ culture medium)

\begin{tabular}{lllll} 
Mutants & \multicolumn{3}{c}{ MPA conc. $\left(\mathrm{\mu g} \mathrm{ml}^{-1}\right)$} \\
\cline { 2 - 5 } & 1st Generation & 2nd generation & 3rd generation & 4th generation \\
\hline Wild type & $6.009 \pm 0.175^{\mathrm{a}}$ & $5.971 \pm 0.184^{\mathrm{a}}$ & $5.492 \pm 0.193^{\mathrm{a}}$ & $5.457 \pm 0.174^{\mathrm{a}}$ \\
\hline MT1 & $12.023 \pm 0.195^{\mathrm{a}, \mathrm{b}}$ & $12.019 \pm 0.157^{\mathrm{a}, \mathrm{b}}$ & $11.509 \pm 0.174^{\mathrm{a}, \mathrm{b}}$ & $11.82 \pm 0.174^{\mathrm{a}, \mathrm{b}}$ \\
\hline MT2 & $10.01 \pm 0.146^{\mathrm{a}, \mathrm{b}}$ & $9.81 \pm 0.163^{\mathrm{a}, \mathrm{b}}$ & $9.416 \pm 0.189^{\mathrm{a}, \mathrm{b}}$ & $9.231 \pm 0.178^{\mathrm{a}, \mathrm{b}}$ \\
\hline MT3 & $9.796 \pm 0.104^{\mathrm{a}, \mathrm{b}}$ & $9.573 \pm 0.158^{\mathrm{a}, \mathrm{b}}$ & $8.972 \pm 0.174^{\mathrm{a}, \mathrm{b}}$ & $8.79 \pm 0.168^{\mathrm{a}, \mathrm{b}}$
\end{tabular}

Data represented as the mean \pm standard deviation (SD). Calculated mean is for triplicate measurements.

a. Statistically significant at $P \leq 0.05$ according to one-way ANOVA.

b. Statistically significant at $P \leq 0.05$ when compared pairwise with the $1^{\text {st }}$ variable (Control) by Tukey's test.

Table (4): Threshold cycles (CT) and fold change to control of mycophenolic acid gene cluster $m p a A, m p a C, m p a F, m p a G$ and mpaH genes and housekeeping gene (B. actin) amplified from wild (HE-MAwt) and mutants (MT1, MT2 and MT3) of penicillium arizonense genome, after 5 and 10 days of incubation. The expression of each gene was defined as the fold change normalized to the reference gene, $B$. actin, and relative to the wild type as a control sample. 


\begin{tabular}{|c|c|c|c|c|c|c|c|c|}
\hline \multirow[b]{2}{*}{ Genes } & \multirow[b]{2}{*}{ Sample } & \multicolumn{3}{|c|}{ After 5 days of Incubation periods } & \multicolumn{3}{|c|}{ After 10 days of incubation } & \multirow[t]{2}{*}{$p_{\text {value }}{ }^{a}$} \\
\hline & & $\begin{array}{l}\text { CT value } \\
\text { of B. actin } \\
\text { gene }\end{array}$ & $\begin{array}{l}\text { CT value of } \\
\text { target gene }\end{array}$ & $\begin{array}{l}\text { Fold change } \\
\text { over control }\end{array}$ & $\begin{array}{l}\text { CT value } \\
\text { of B. actin } \\
\text { gene }\end{array}$ & $\begin{array}{l}\text { CT value } \\
\text { of target } \\
\text { gene }\end{array}$ & $\begin{array}{l}\text { Fold change } \\
\text { over control }\end{array}$ & \\
\hline \multirow[t]{4}{*}{$\mathrm{mpaA}$} & $\begin{array}{l}\text { Wild } \\
\text { type } \\
\text { (control) }\end{array}$ & $21.24 \pm 0.98$ & $23.00 \pm 3.50$ & - & $20.29 \pm 1.01$ & $0.00 \pm 0.00$ & - & - \\
\hline & MT1 & $20.56 \pm 1.23$ & $21.66 \pm 0.37$ & $1.58 \pm 0.09^{c}$ & $19.41 \pm 1$ & $21.70 \pm 0.69$ & $1.4845 \pm 0.16^{c}$ & $0.037^{a}$ \\
\hline & MT2 & $20.08 \pm 1.17$ & $21.38 \pm 1.23$ & $1.3755 \pm 0.35^{c}$ & $20.55 \pm 1.13$ & $21.65 \pm 1.23$ & $1.567 \pm 0.17^{c}$ & $0.013^{a}$ \\
\hline & MT3 & $20.17 \pm 1.0$ & $22.12 \pm 0.90$ & $0.8766 \pm 0.1^{c}$ & $20.62 \pm 0.71$ & $20.20 \pm 0.72$ & $1.1892 \pm 0.1^{\mathrm{c}}$ & $0.033^{a}$ \\
\hline \multicolumn{2}{|c|}{ p value ${ }^{b}$} & & & $<0.001^{b}$ & & & $<0.001^{b}$ & \\
\hline \multirow[t]{4}{*}{$\mathrm{mpaC}$} & $\begin{array}{l}\text { Wild } \\
\text { type } \\
\text { (control) }\end{array}$ & $21.24 \pm 1.78$ & $22.60 \pm 0.92$ & - & $20.29 \pm 1.03$ & $24.21 \pm 0.88$ & - & - \\
\hline & MT1 & $20.56 \pm 1.02$ & $20.89 \pm 1.16$ & $2.0420 \pm 0.109^{c}$ & $20.55 \pm 2.30$ & $22.85 \pm 1.88$ & $8.4561 \pm 1.02^{c}$ & $0.003^{a}$ \\
\hline & MT2 & $20.08 \pm 0.16$ & $21.02 \pm 1.0$ & $1.3379 \pm 0.13^{c}$ & $19.41 \pm 1.0$ & $22.94 \pm 0.99$ & $3.8637 \pm 0.10^{c}$ & $0.003^{a}$ \\
\hline & MT3 & $20.17 \pm 0.92$ & $22.28 \pm 1.77$ & $0.5946 \pm 0.14^{c}$ & $20.62 \pm 0.71$ & $24.44 \pm 0.79$ & $1.2924 \pm 0.10$ & $0.001^{\mathrm{a}}$ \\
\hline \multicolumn{2}{|c|}{ p value } & & & $<0.001^{b}$ & & & $<0.001^{b}$ & \\
\hline \multirow[t]{4}{*}{ mpaF } & $\begin{array}{l}\text { Wild } \\
\text { type } \\
\text { (control) }\end{array}$ & $21.24 \pm 0.92$ & $23.92 \pm 0.77$ & - & $20.29 \pm 1.11$ & $24.18 \pm 0.97$ & - & - \\
\hline & MT1 & $20.56 \pm 1.67$ & $21.59 \pm 2.14$ & $3.1383 \pm 0.13^{c}$ & $20.55 \pm 1.77$ & $21.94 \pm 1.93$ & $5.6569 \pm 0.87^{c}$ & $0.012^{a}$ \\
\hline & MT2 & $20.08 \pm 1.11$ & $21.40 \pm 0.80$ & $2.5669 \pm 0.31^{c}$ & $19.41 \pm 0.59$ & $21.70 \pm 1.11$ & $3.0314 \pm 0.08^{c}$ & 0.177 \\
\hline & MT3 & $20.17 \pm 1.08$ & $22.04 \pm 1.01$ & $1.7532 \pm 0.79^{c}$ & $20.62 \pm 0.82$ & $23.31 \pm 1.3$ & $2.2974 \pm 0.3^{c}$ & 0.206 \\
\hline \multicolumn{2}{|c|}{$p$ value ${ }^{b}$} & & & $<0.001^{b}$ & & & $<0.001^{b}$ & \\
\hline \multirow[t]{4}{*}{ mpaG } & $\begin{array}{l}\text { Wild } \\
\text { type } \\
\text { (control) }\end{array}$ & $21.24 \pm 0.81$ & $22.89 \pm 1.96$ & - & $20.29 \pm 1.0$ & $24.21 \pm 1.19$ & - & - \\
\hline & MT1 & $20.56 \pm 0.82$ & $20.85 \pm 1.89$ & $2.5669 \pm 0.62^{c}$ & $20.55 \pm 0.58$ & $22.85 \pm 1.88$ & $3.0738 \pm 0.11^{c}$ & 0.094 \\
\hline & MT2 & $20.08 \pm 0.99$ & $20.96 \pm 0.95$ & $1.7053 \pm 0.11^{c}$ & $19.41 \pm 0.59$ & $22.94 \pm 0.92$ & $1.3104 \pm 0.41^{c}$ & 0.087 \\
\hline & MT3 & $20.17 \pm 0.88$ & $22.30 \pm 0.40$ & $0.7170 \pm 0.19^{c}$ & $20.62 \pm 0.32$ & $24.44 \pm 0.58$ & $1.0718 \pm 0.06^{c}$ & $0.021^{a}$ \\
\hline \multicolumn{2}{|c|}{$p$ value $e^{b}$} & & & $<0.001^{b}$ & & & $<0.001^{b}$ & \\
\hline \multirow[t]{4}{*}{$\mathrm{mpaH}$} & $\begin{array}{l}\text { Wild } \\
\text { type } \\
\text { (control) }\end{array}$ & $21.24 \pm 0.82$ & $22.40 \pm 0.7$ & - & $20.29 \pm 0.63$ & $24.53 \pm 0.79$ & - & - \\
\hline & MT1 & $20.56 \pm 0.7$ & $20.73 \pm 0.83$ & $1.9862 \pm 0.21^{c}$ & $20.55 \pm 1.26$ & $22.58 \pm 0.71$ & $4.6268 \pm 0.18^{c}$ & $<0.001^{a}$ \\
\hline & MT2 & $20.08 \pm 1.02$ & $20.92 \pm 0.94$ & $1.2483 \pm 0.09^{c}$ & $19.41 \pm 0.62$ & $22.10 \pm 1.10$ & $2.9282 \pm 0.21^{c}$ & $0.010^{a}$ \\
\hline & MT3 & $20.17 \pm 0.99$ & $22.33 \pm 0.69$ & $0.50 \pm 0.08^{c}$ & $20.62 \pm .68$ & $23.90 \pm 0.24$ & $1.9453 \pm 0.18^{c}$ & $0.002^{\mathrm{a}}$ \\
\hline \multicolumn{2}{|c|}{$p$ value ${ }^{b}$} & & & $<0.001^{b}$ & & & $<0.001^{b}$ & \\
\hline
\end{tabular}


a: Statistically significant at $P<0.05$ according to paired $t$ test.

b: Statistically significant at $\mathrm{P}<0.05$ according to one-way ANOVA.

c: Statistically significant at $\mathrm{P}<0.0125$ according to post hoc adjusted by Bonferroni's corrections for pairwise comparison using the wild type (as a control).

\section{Figures}

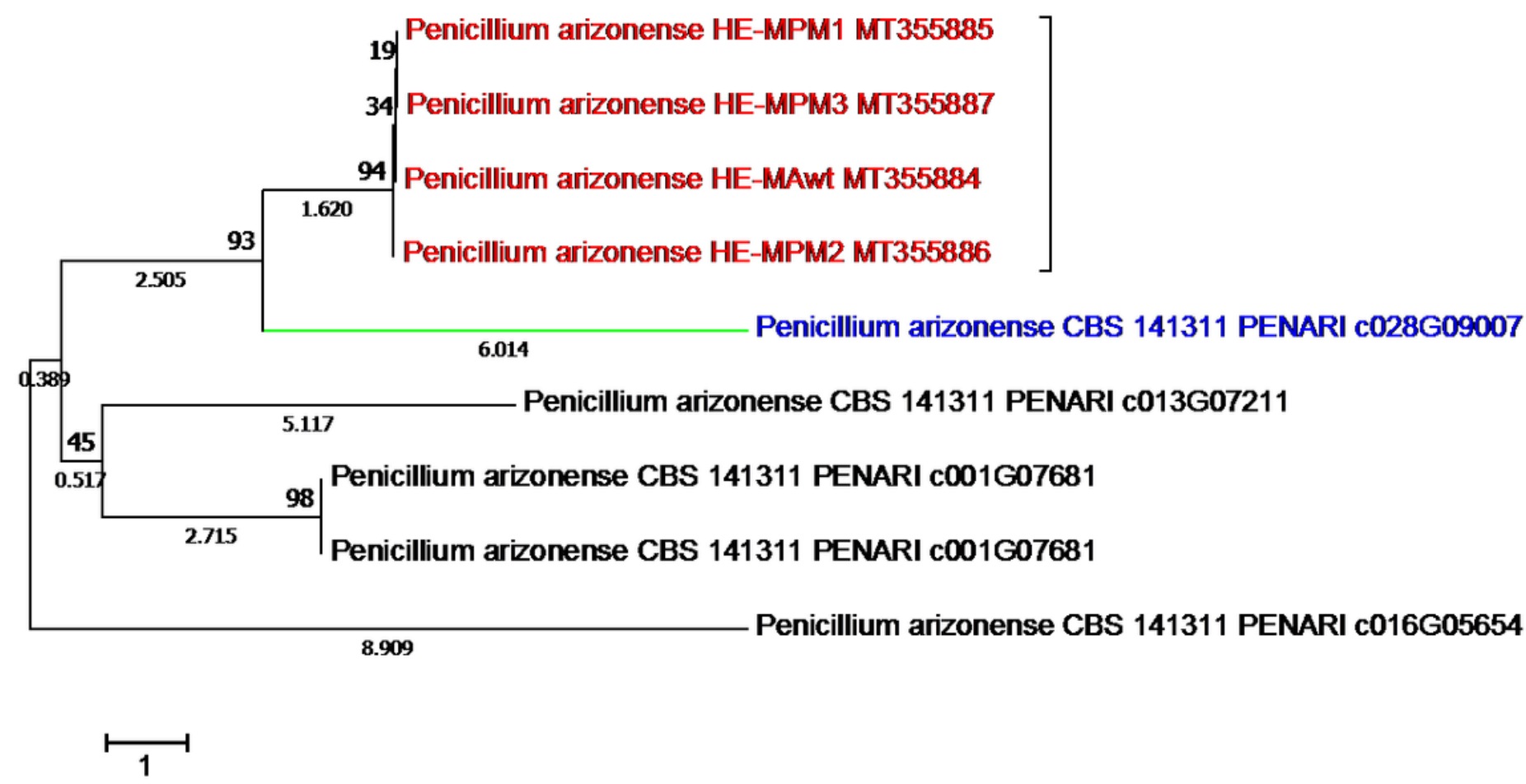

Figure 1

Phylogenetic analysis of $P$. arizonense HE-MAwt (MT355884) and the mutant strains HE-MPM1 (MT355885), HE-MPM2 (MT355886), HE-MPM1 (MT355887), showing ITS relationship with the ITS sequences of each other with the ITS sequences of the closely related strains retrieved from NCBI GenBank database. The percentage of replicate trees in which the associated taxa clustered together in the bootstrap test (1000 replicates) are shown next to each branch. The tree is drawn to scale, with a branch length in the same unit as those of the evolutionary distance used to infer the phylogenetic tree. The evolutionary distance was computed using the Maximum Composite Likelihood method and is in the units of the number of base substitutions per site. Evolutionary analyses were conducted in the MEGAX program. Our strains are shown in red color and the most closely related strain is detected in blue color. 


\section{ST WT M1 M2 M3}

\section{Figure 2}

TLC analysis of MPA produced by the wild-type strain $P$. arizonense HE-MPwt (WT) and the MPA overproducer mutant strains $P$. arizonense HE-MPM1 (M1), MPM2 (M2), and MPM3 (M3), in front of the reference standard of MPA solution (ST)
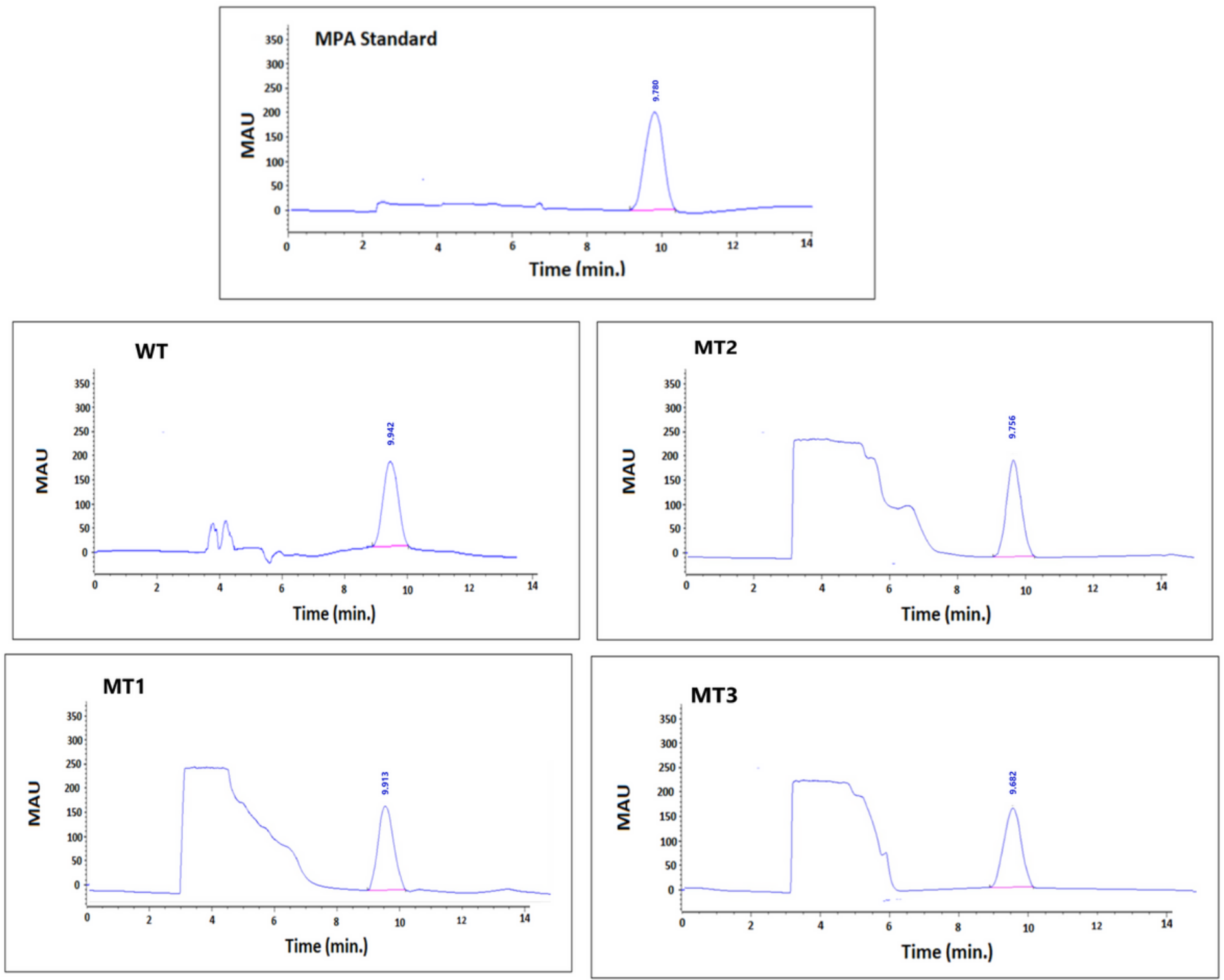
Figure 3

Quantitative analysis of MPA produced by wild type $P$. arizonense HE-MAwt (WT) and mutant strains HE-MPM1 (M1), HE-MPM2 (M2), HE-MPM1 (MT3) in presence of standard MPA, using HPLC technique.
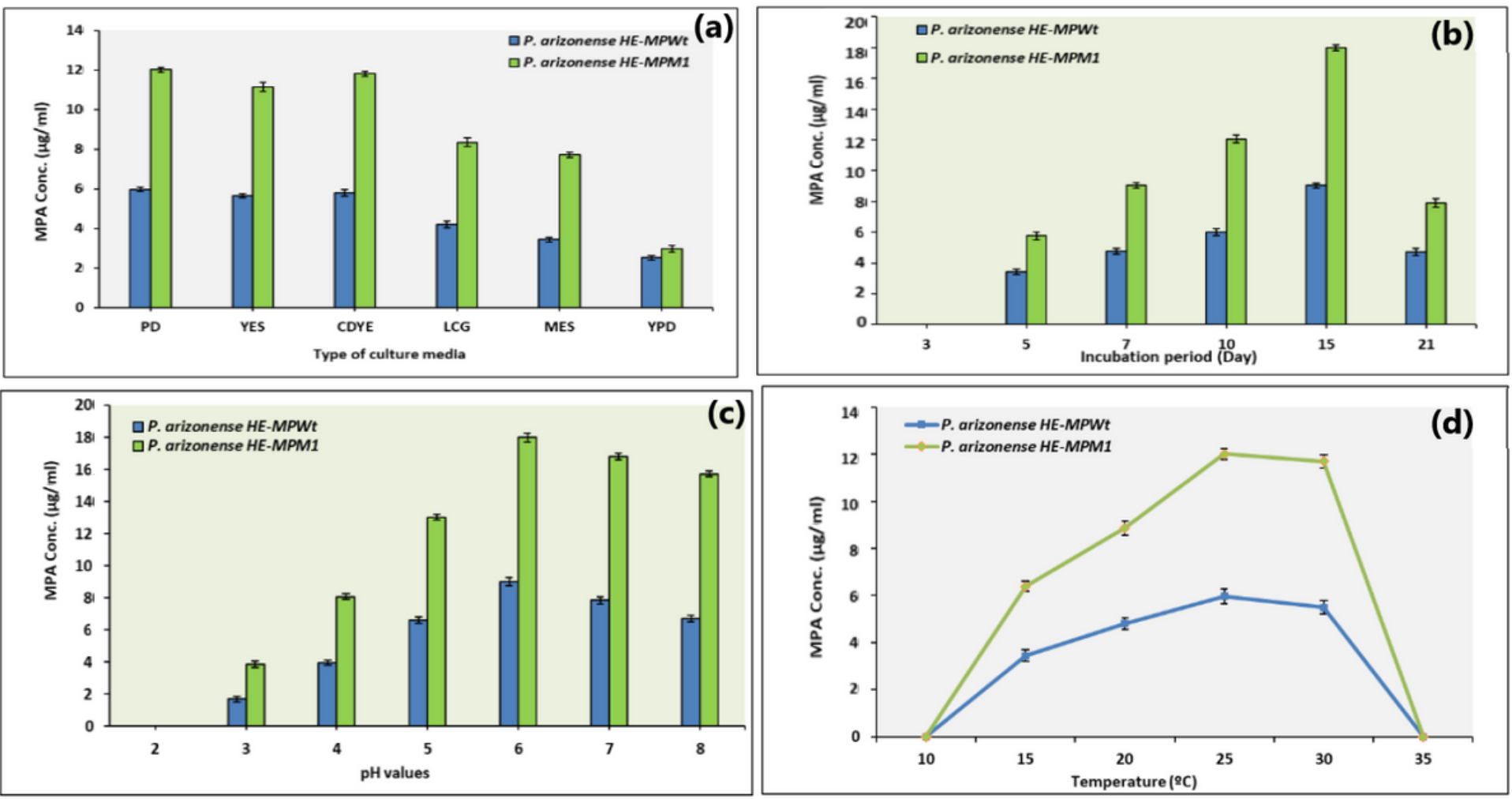

\section{Figure 4}

Error bar chart of the change in the mean MPA concentrations $\left(\mu \mathrm{g} \mathrm{ml}^{-1}\right)$ produced by $P$. arizonense HE-MPWt and $P$. arizonense HE-MPM1 grown at different culture media (a) and incubated at different incubation times (b). The culture media were adjusted to different $\mathrm{pH}$ values (c) and incubated at different temperatures (d). Data are shown as the mean \pm SD of triplicate measurements from two independent experiments.

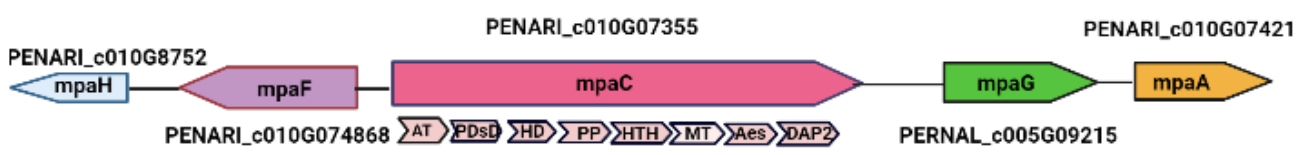

(a)

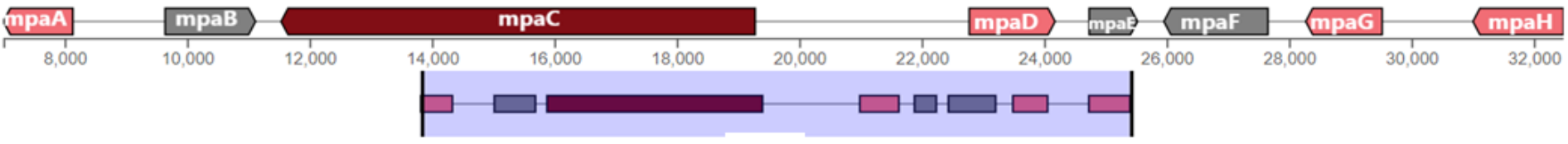

(b)

Figure 5 
Orthologue gene cluster of MPA biosynthesis genes ( $m p A, m p C, m p F, m p G$, and $m p G)$ in $P$. arizonense (a) vs. MPA biosynthesis gene cluster in P. brevicompactum (HQ731031.1) retrieved from MIBiG database (b).

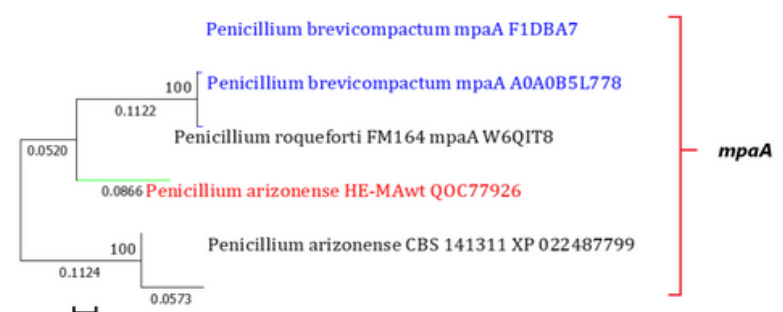

$\stackrel{502}{0.02}$
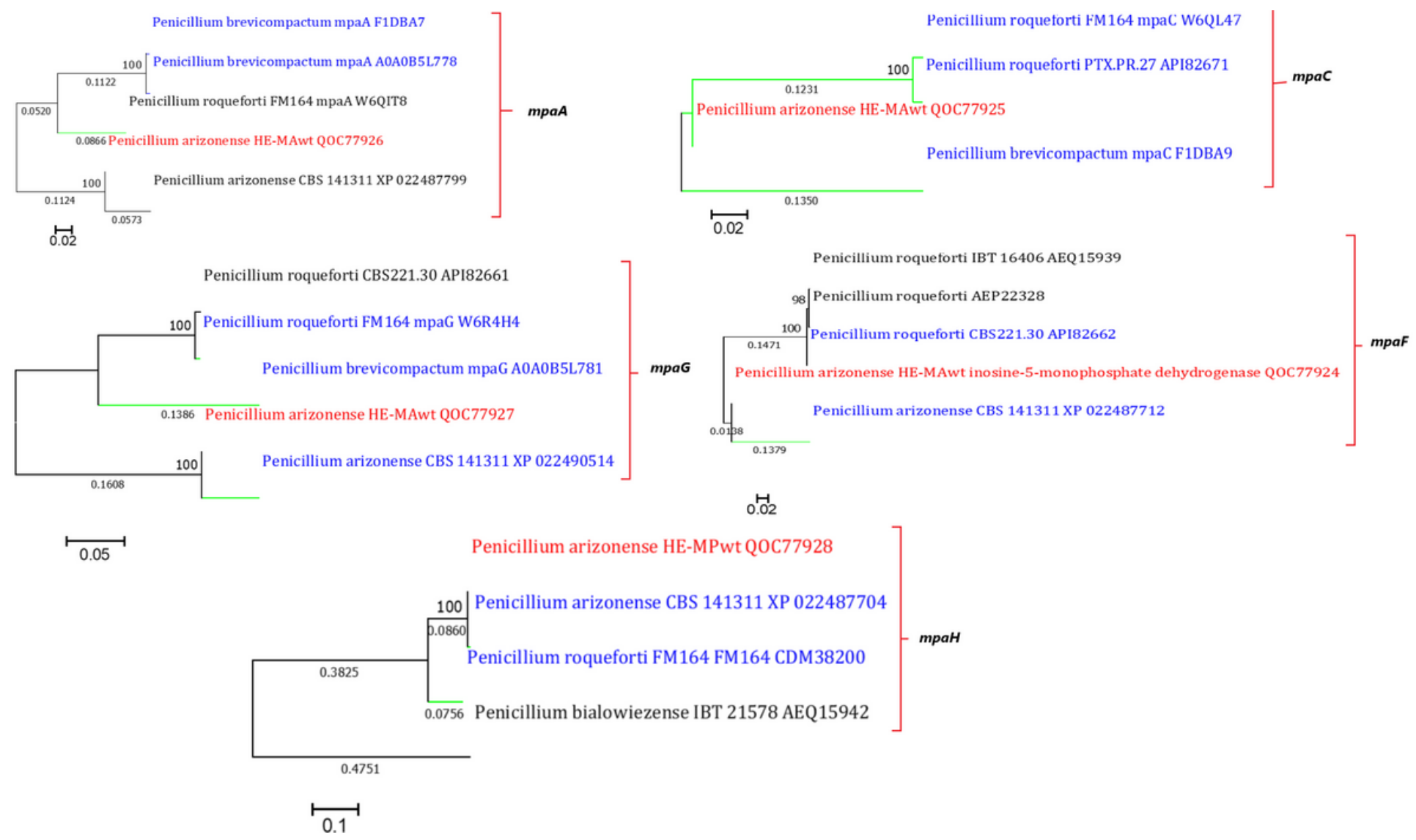

\section{Figure 6}

Phylogenetic analysis of MPA gene cluster orthologues to (mpaA, mpaC, $\mathrm{mpaF}, \mathrm{mpaG}$, and $\mathrm{mpaH}$ ) of $P$. arizonense with closely related genes of Penicillium strains retrieved from NCBI GenBank. The analysis was conducted by constructing a rooted tree using the UPGMA method in the MEGAX program. The percentage of replicate trees in which the associated taxa clustered together in the bootstrap test (1000 replicates) is shown next to each branch. 

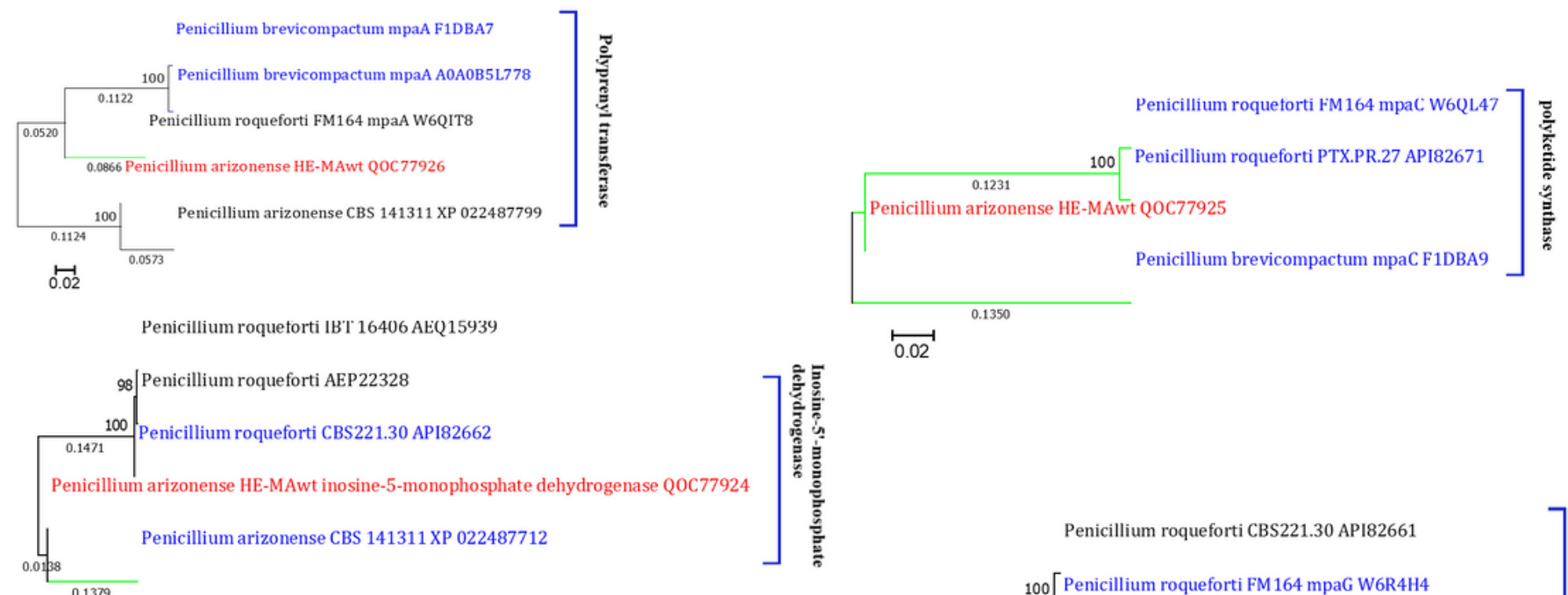

Penicillium roqueforti IBT 16406 AEQ15939

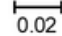

$\stackrel{1.02}{0.02}$
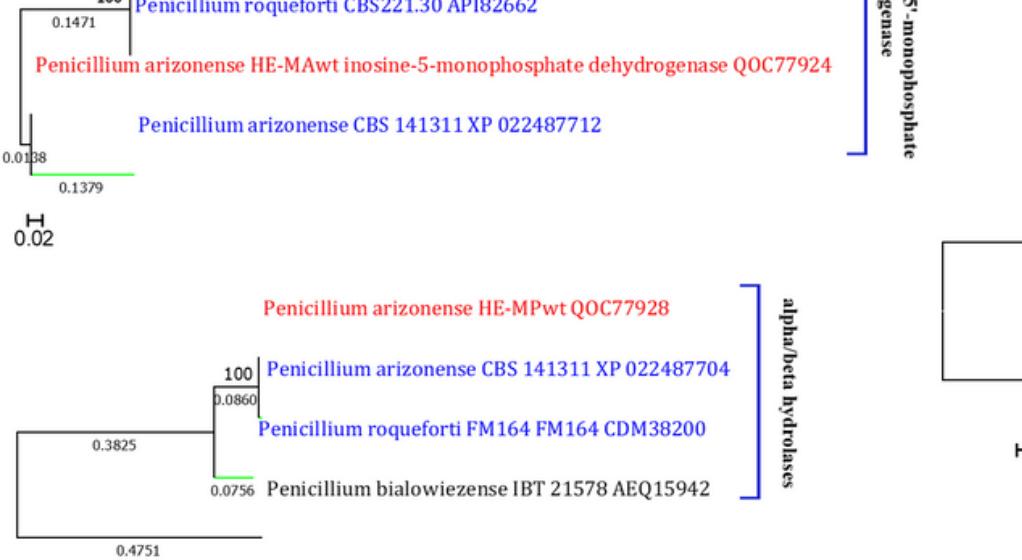

$\longmapsto$

\section{Figure 7}

Phylogenetic analysis of putative protein in P. arizonense HE-MPwt responsible for MPA biosynthesis gene clusters with closely related protein of Penicillium strains retrieved from NCBI GenBank. The analysis was conducted by constructing a rooted tree using the UPGMA method in the MEGAX program. The percentage of replicate trees in which the associated taxa clustered together in the bootstrap test (1000 replicates) is shown next to each branch. 


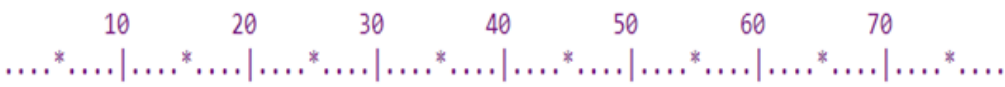

gi 19094229081 IAAGADGLRIGMGSDSACITQEVMAVGRPQAAAVRSVAFAARFGVPTIADGGVQNLGHIVKGLALGDSAVMMGSLLAG 79

Cdd:PTZ00314 300 IDAGADGLRIGMGSGSICITQEVCAVGRPQASAVYHVARYARERGVPCIADGGIKNSGDICKALALGADCVMLGSLLAG 378

methyltransferases

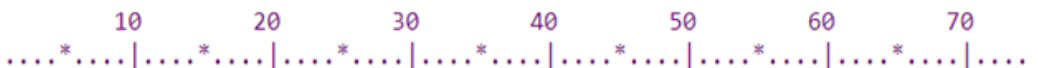

gi 19094229141 ARAYSLHSILHDWSDEDGVRILENLVPALKKGYSRVLLNEIVVSEE-HPTLAATSMDMMMLAHFAVRERTEAEW 73

Cdd:pfam00891 126 ADAYILKRVLHDWSDEKCVKLLKRCYKACPAG-GKVILVESLLGADPSGPLHTQLYSLNMLAQTEGRERTEAEY 198

\section{O-methyltransferases}

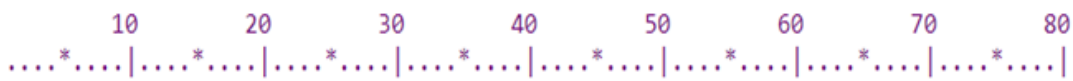

gi 19094229161 DNFWLIGEDKFLNPKDFFIIITALFGNGQSSSPSNQPAPG---PFPKVSFYDNVRAQHELVTKHFGITHLRAVVGWSMG 77

Cdd:PRK07581 56 DNEWLIGPGRALDPEKYFIIIPNMFGNGLSSSPSNTPAPFnaRRFHVTIYDNVRAQHRLLTEKFGIERLALVVGWSMGA 135

$$
\text { ........ }
$$

gi 190942291678 AQSFQWATQY 87

Cdd:PRK07581 136 QQTYHWAVRY 145

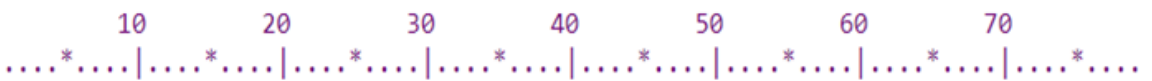

gi 19094229123 LMLPLTATIIVYPYLKRPVfSkVFIYPQYVLGLAVSYPAITGWASINGqdqSTaDIVNHCAPIVLLVFFWCLYFNTAYS 81

Cdd:cd13959 107 LSPIALLLVLIYPLMKR -..--FTYWPQLVLGLAFGWGPLMGWAAVTG-...--SLPLPALLLYLAVIFWTAGYDTIYA 174

prenyltransferases (PTases)

\section{Figure 8}

A conserved region of putative protein of MPA gene cluster with respective protein family, gi: our amino acid sequences of MPA gene cluster, cdd: conserved domain of protein family. 


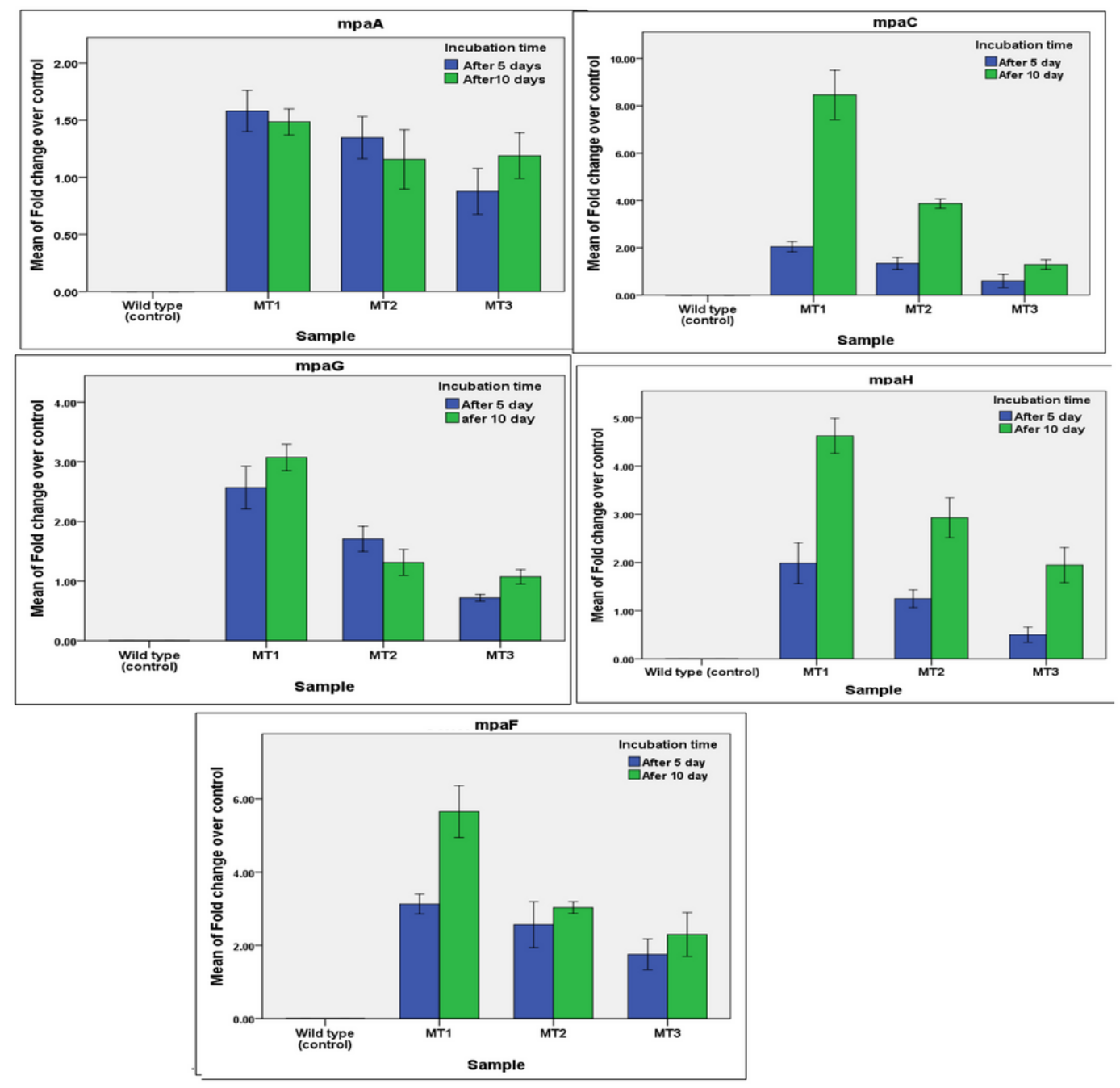

Figure 9

Gene expression analysis of MPA gene cluster after incubation of overproducer mutant $P$. arizonense HE-MPM1 for 5 and $10 \mathrm{~d}$ on MPA producer culture medium compared with the expression of MPA gene cluster in the wild type $P$. arizonense HE-MAwt incubated at the same environmental conditions. Data are shown as the mean \pm SD of triplicate measurements from two independent experiments.

\section{Supplementary Files}

This is a list of supplementary files associated with this preprint. Click to download.

- Sup.Fig..docx 